\title{
Standardy leczenia żywieniowego w onkologii
}

\author{
Stanisław Kłęk ${ }^{1}$, Michał Jankowski ${ }^{2}$, Wiesław Janusz Kruszewski ${ }^{3}$, Jacek Fijuth ${ }^{4}$, \\ Aleksandra Kapała ${ }^{5}$, Paweł Kabata ${ }^{6}$, Piotr Wysocki ${ }^{7}$, Maciej Krzakowski ${ }^{5}$, Piotr Rutkowski ${ }^{8}$
}

\author{
Rekomendacje: \\ Polskiego Towarzystwa Chirurgii Onkologicznej (PTChO) \\ Polskiego Towarzystwa Onkologicznego (PTO) \\ Polskiego Towarzystwa Onkologii Klinicznej (PTOK) \\ Polskiego Towarzystwa Żywienia Pozajelitowego, Dojelitowego i Metabolizmu (POLSPEN)
}

Niedożywienie dotyczy dużej części pacjentów onkologicznych. Prawidłowe postępowanie żywieniowe warunkuje skuteczność i powodzenie leczenia u tych chorych. Ze względu na znaczenie tego zagadnienia, dzięki współpracy towarzystw naukowych: Polskiego Towarzystwa Chirurgii Onkologicznej (PTChO), Polskiego Towarzystwa Onkologicznego (PTO), Polskiego Towarzystwa Onkologii Klinicznej (PTOK) oraz Polskiego Towarzystwa Żywienia Dojelitowego, Pozajelitowego i Metabolizmu (POLSPEN), zostały opracowane standardy leczenia żywieniowego w onkologii. Wstępem do leczenia żywieniowego jest prawidłowa identyfikacja niedożywionych pacjentów. W Polsce hospitalizowani chorzy są poddawani badaniu przesiewowemu w kierunku niedożywienia. Interwencja żywieniowa powinna być dostosowana do sytuacji klinicznej. Polega ona na poradnictwie dietetycznym, stosowaniu doustnych diet przemysłowych (oral nutritional support), żywienia dojelitowego lub żywienia pozajelitowego w warunkach szpitalnych i domowych, z uwzględnieniem sytuacji szczególnych.

\section{Clinical nutrition in oncology: Polish recommendations}

Malnutrition affects a large part of patients with malignant neoplasm. Proper nutritional treatment determines the effectiveness and success of therapy in these patients. Given the importance of this issue, thanks to the collaboration of scientific societies: Polish Society of Surgical Oncology (PTChO), Polish Society of Oncology (PTO), Polish Society of Clinical Oncology (PTOK) and Polish Society for Parenteral, Enteral Nutrition and Metabolism (POLSPEN) standards for nutritional therapy in oncology have been set. An introduction to nutritional therapy is the correct identification of malnourished patients. In Poland, hospitalized patients are subject to screening towards malnutrition. Nutrition

\footnotetext{
${ }^{1}$ Oddział Chirurgii Ogólnej i Onkologicznej, Szpital Wielospecjalistyczny im. Stanley Dudricka w Skawinie ${ }^{2}$ Klinika Chirurgii Onkologicznej Collegium Medicum, Uniwersytet Mikołaja Kopernika Centrum Onkologii w Bydgoszczy

${ }^{3}$ Zakład Propedeutyki Onkologii, Gdański Uniwersytet Medyczny oraz Oddział Chirurgii Onkologicznej Gdyńskie Centrum Onkologii, Szpitale Wojewódzkie w Gdyni, sp. z o.o

${ }^{4}$ Zakład Radioterapii Katedry Onkologii

Uniwersytet Medyczny w Łodzi

${ }^{5}$ Centrum Onkologii — Instytut im. Marii Skłodowskiej-Curie w Warszawie

${ }^{6}$ Klinika Chirurgii Onkologicznej

Gdański Uniwersytet Medyczny

${ }^{7}$ Zachodniopomorskie Centrum Onkologii w Szczecinie

${ }^{8}$ Klinika Nowotworów Tkanek Miękkich, Kości i Czerniaków

Centrum Onkologii — Instytut im. Marii Skłodowskiej-Curie w Warszawie
} 
intervention should be tailored to the clinical situation. It involves the use of dietary advice, use of oral diet products (oral nutritional support), enteral or parenteral nutrition, in hospital or in home, in consideration of special situations.

NOWOTWORY Journal of Oncology 2015; 65, 4: 320-337

Słowa kluczowe: terapia żywieniowa, onkologia, żywienie dojelitowe, żywienie pozajelitowe

Key words: nutrition therapy, oncology, enteral nutrition, parenteral nutrition

\section{Wstęp}

Niedożywienie stanowi poważny problem u pacjentów z chorobą nowotworową. Objawy niedożywienia lub wyniszczenia występują u 30-85\% chorych, najczęściej towarzyszą chorobie w stadium uogólnienia. U 5-20\% chorych wyniszczenie jest bezpośrednią przyczyną zgonu w terminalnym okresie choroby.

Częstość niedożywienia i wyniszczenia zależy od rodzaju nowotworu, stopnia jego zaawansowania i wieku chorego. Najbardziej narażone na wyniszczenie są dzieci i osoby w podeszłym wieku, chorzy na nowotwory układu pokarmowego (zwłaszcza raka żołądka, przełyku oraz trzustki), głowy i szyi, płuca oraz gruczołu krokowego. Nasilenie zaburzeń jest często proporcjonalne do zaawansowania choroby. Wynikiem niedożywienia jest zwiększenie liczby powikłań, w tym śmiertelności, wydłużenie czasu pobytu w szpitalu oraz znaczące zwiększenie kosztów opieki zdrowotnej.

Należy podkreślić, że nie ma wiarygodnych danych klinicznych wskazujących na ryzyko przyspieszenia wzrostu nowotworu i rozwoju choroby wskutek stosowania leczenia żywieniowego. Wiadomo również, że głodówka nie hamuje rozwoju nowotworu, ale istotnie pogarsza stan chorego — w rezultacie śmierć z powodu niedożywienia może nastąpić szybciej niż z powodu samej choroby.

\section{Patogeneza}

Niedożywienie najczęściej jest wynikiem braku pokrycia zapotrzebowania na składniki odżywcze, ale może się również rozwijać w wyniku zwiększonego zapotrzebowania na te składniki lub ich utraty. U pacjentów z chorobą nowotworową do niedożywienia dochodzi najczęściej w mechanizmie kacheksji, która jest zespołem zaburzeń powstających w wyniku ogólnoustrojowej reakcji zapalnej będącej odpowiedzią na obecność choroby nowotworowej w organizmie. Wyniszczenie w chorobie nowotworowej jest zjawiskiem złożonym - w jego patogenezie uczestniczy wiele czynników, wśród których wyróżnia się:

- zaburzenia odżywiania drogą doustną (brak łaknienia rozwijający się wtórnie do przewlekłego stanu zapalnego, mechaniczne utrudnienie pasażu pokarmu w przewodzie pokarmowym);
- zwiększenie utraty substancji odżywczych (zaburzenia wchłaniania lub trawienia, enteropatia wysiękowa lub obecność przetoki przewodu pokarmowego);

- zaburzenia procesów metabolicznych (nasilenie aktywności cyklu Cori, zwiększenie utylizacji białek, zaburzenia metabolizmu węglowodanów i tłuszczów);

- nasilenie reakcji zapalnych wskutek działania prozapalnych cytokin, np. czynnika martwicy guza typu a (TNFa - tumor necrosis factor a) lub interleukiny $1 \mathrm{~b}$ i 6 - IL-1b i IL-6);

- nasilenie procesów katabolicznych przez czynniki krążące, np. czynnik mobilizujący tłuszcz (LMF — lipid mobilizing factor) i czynnik mobilizujący białko (PMF — protein mobilizing factor);

— zwiększenie zapotrzebowania związane z nowotworem lub współwystępującymi chorobami (np. zakażeniem);

- zwiększenie wydatku energetycznego (zwykle niewielkie - 100-300 kcal/dobę - jednak mogące mieć związek z utratą tkanki tłuszczowej w tempie ok. 0,5-1 kg miesięcznie lub masy mięśniowej w tempie 1-2,3 kg miesięcznie w przypadkach braku kompensacji przez zwiększone spożycie);

- działania niepożądane leczenia przeciwnowotworowego (utrata łaknienia, zaburzenia odczuwania smaku i zapachu, nudności i wymioty, biegunki).

\section{Ocena stanu odżywienia}

\subsection{Badania przesiewowe}

Mają za zadanie wykryć pacjentów niedożywionych, zagrożonych niedożywieniem oraz z dużym ryzykiem żywieniowym. Przesiewowa ocena ryzyka niedożywienia jest w Polsce obowiązkowa na wszystkich oddziałach szpitalnych - przy przyjęciu do szpitala wykorzystuje się ankiety: Subiektywną Globalną Ocenę Stanu Odżywienia (SGA — Subjective Global Assessment) lub formularz przesiewowej oceny ryzyka związanego z niedożywieniem NRS 2002 (Nutritional Risk Screening 2002), które należy powtarzać co 14 dni.

Ankieta NRS 2002 jest tak skonstruowana, by na jej podstawie można było określić ryzyko żywieniowe, a zarazem ustalić wskazania do leczenia żywieniowego; wynik podawany jest w skali liczbowej od 0 do 7 punktów (załącznik 1). Cztery pytania dotyczą oceny stopnia niedożywienia przed 
Tabela I. Objawy i czynniki związane z niedożywieniem

Czas trwania zaburzeń w przyjmowaniu pokarmów
Mimowolna utrata masy ciała w ostatnich 3 miesiącach
Zwyczaje żywieniowe i ich zmiany
Zaburzenia łaknienia, dysfagia
Stosowanie leków
Bóle kostne, bóle mięśniowe
Biegunka
Osłabienie
Obniżenie funkcji emocjonalnych
Zaburzenia snu

hospitalizacją, a pozostałe cztery służą ocenie wpływu czynników ryzyka podczas proponowanego leczenia. Chorzy po 70. roku życiu otrzymują dodatkowy punkt. Liczba punktów powyżej 3 jest wskazaniem do wdrożenia leczenia żywieniowego.

Innym narzędziem służącym do oceny ryzyka jest ankieta SGA (załącznik 2). Na podstawie uzyskanego wyniku kwalifikuje się pacjenta do jednej z grup: prawidłowego stanu odżywienia, podejrzenia niedożywienia lub niedożywienia średniego stopnia, wyniszczenia dużego ryzyka żywieniowego (to ostatnie określenie można spotkać w niektórych wersjach skali).

Inna ankieta - uniwersalna przesiewowa metoda oceny niedożywienia (MUST - Malnutrition Universal Screening Tool) jest zalecana przez Brytyjskie Towarzystwo Żywienia Pozajelitowego i Dojelitowego (BAPEN — British Association forParenteral and Enteral Nutrition) do oceny niedożywienia u dorosłych. U osób starszych zalecana jest miniskala oceny stanu odżywienia (MNA — Mini Nutritional Assessment).

W wielu publikacjach sugeruje się łączenie ankiet, aby w ten sposób zwiększyć czułość wykrywania niedożywienia.

\subsection{Ocena: wywiad, ankiety, badania laboratoryjne i antropometryczne}

W przypadku ryzyka niedożywienia lub jego obecności powinna zostać wykonana ocena stanu odżywienia. W praktyce klinicznej sprowadza się to do zebrania wywiadu, wypełnienia ankiet, wykonania badań antropometrycznych i laboratoryjnych. Ocena stanu odżywienia opiera się zawsze na kilku metodach.

\subsubsection{Wywiad}

Wywiad jest najprostszym elementem oceny stanu odżywienia. Opiera się na sprawdzeniu obecności objawów, jakie towarzyszą niedożywieniu (tab. I). Osobnym elementem jest zebranie informacji o czasie trwania objawów. Wiele z nich może być specyficznych dla poszczególnych chorób i mogą sugerować rozpoznanie (np. zaburzenia przełykania w przypadku guzów przełyku).
Tabela II. BMI jako wskaźnik stanu odżywienia

\begin{tabular}{lc}
\hline Niedożywienie & $<18,5$ \\
Zagrożenie & $18,5-20$ \\
Norma & $20-25$ \\
Nadwaga & $25-30$ \\
Otyłość & $>30$ \\
\hline
\end{tabular}

\subsubsection{Ankiety (skale)}

Ankiety wykorzystywane do oceny stanu odżywienia są identyczne jak te stosowane w badaniach przesiewowych. Zdaniem European Society for Clinical Nutrition and Metabolism (ESPEN) ankietą preferowaną do oceny chorych hospitalizowanych jest ankieta NRS 2002, dzięki której można ocenić ryzyko żywieniowe. Innym badaniem rekomendowanym dla dorosłych jest ankieta MUST, która opiera się na związku pomiędzy upośledzeniem stanu odżywienia a upośledzeniem funkcji organizmu.

W wielu publikacjach sugeruje się łączenie ankiet, aby w ten sposób poprawić swoistość i czułość oceny.

\subsubsection{Badanie przedmiotowe}

W trakcie badania przedmiotowego należy zwrócić uwagę na wychudzenie, utratę tkanki podskórnej, stany zapalne dziąseł i jamy ustnej. W zaawansowanym niedożywieniu są obecne wysięki w jamach opłucnowych, wodobrzusze, pojawiają się bóle i zaniki mięśniowe. Osobny, specyficzny obraz kliniczny jest spotykany w przypadku niedożywień typu marasmus lub kwashiorkor.

\subsubsection{Badania antropometryczne}

Podstawowym badaniem jest pomiar wagi ciała. Innym parametrem jest indeks masy ciała (BMI — body mass index)

$$
\mathrm{BMI}=\frac{\text { masa ciała }(\mathrm{kg})}{\text { wzrost }(\mathrm{m})^{2}}
$$

Wskaźnik BMI jest prostym narzędziem pomocnym w ocenie stanu odżywienia (tab. II). Nie należy go jednak stosować u kobiet w ciąży, dzieci i osób starszych oraz u osób z rozwiniętą masą mięśniową. Nie jest także wiarygodny w wielu stanach patologicznych, jak uogólnione obrzęki czy wodobrzusze.

W celu prawidłowego zaplanowania leczenia żywieniowego konieczne jest obliczenie należnej masy ciała. Można to zrobić na przykład według wzoru Broca:

$$
\text { idealna masa ciała }=\text { wzrost }(\mathrm{cm})-100
$$

lub bardziej szczegółowo według Lorentza (20-40 rż.) dla mężczyzn:

idealna m.c. $=$ wzrost $(\mathrm{cm})-100-[$ wzrost $(\mathrm{cm})-150] / 4$ 
Tabela III. Wskaźniki biochemiczne a stan odżywienia

\begin{tabular}{|c|c|c|c|c|}
\hline Niedożywienie & Albumina & Transferryna & Prealbumina & CLL \\
\hline Norma & $>35 \mathrm{~g} / \mathrm{l}$ & $>200 \mathrm{mg} / \mathrm{dl}$ & $>20 \mathrm{mg} / \mathrm{dl}$ & $1500-2000$ \\
\hline Lekkie & $30-35 \mathrm{~g} / \mathrm{l}$ & $150-200 \mathrm{mg} / \mathrm{dl}$ & $10-20 \mathrm{mg} / \mathrm{dl}$ & $1200-1500$ \\
\hline Średnie & $24-29 \mathrm{~g} / \mathrm{l}$ & $100-150 \mathrm{mg} / \mathrm{dl}$ & $5-10 \mathrm{mg} / \mathrm{dl}$ & $800-1200$ \\
\hline Ciężkie & $<24 \mathrm{~g} / \mathrm{l}$ & $<100 \mathrm{mg} / \mathrm{dl}$ & $<5 \mathrm{mg} / \mathrm{dl}$ & $<800$ \\
\hline
\end{tabular}

CLL — całkowita liczba leukocytów

dla kobiet:

idealna m.c. $=$ wzrost $(\mathrm{cm})-100-[$ wzrost $(\mathrm{cm})-150] / 2$

Badaniem antropometrycznym, na podstawie którego opisuje się stan odżywienia, jest pomiar grubości fałdu tłuszczowego. Podstawą do oceny jest to, że 20-25\% masy ciała stanowi tkanka tłuszczowa, w 50\% przechowywana w tkance podskórnej. Pomiar wykonuje się nad mięśniem trójgłowym niedominującej kończyny. Na podstawie tego badania opisuje się tłuszczowe zasoby organizmu, przy założeniu wpływu takich czynników jak płeć i wiek, a wynik jest odczytywany z odpowiednich tabel. Inne badania antropometryczne to obwód ramienia lub siła ucisku dłoni.

Nowoczesną metodą określenia składu ciała jest pomiar i analiza bioimpedancyjna (BIA - bioelectrical impedance analysis). Badanie polega na zmierzeniu różnic w impedancji (rodzaju oporu elektrycznego) tkanek, przez które jest przepuszczany prąd elektryczny o niskim natężeniu, dzięki czemu można łatwo określić tłuszczową i beztłuszczową masę ciała. Metoda jest nieinwazyjna i powtarzalna.

\subsubsection{Badania biochemiczne}

Badania biochemiczne umożliwiają powtarzalną i obiektywną ocenę stanu odżywienia. Najczęściej stosuje się oznaczanie stężenia: albuminy, prealbuminy, transferryny i całkowitej liczby limfocytów (tab. III).

Albumina — niskie stężenie albuminy tylko w części przypadków jest spowodowane niedożywieniem. W przypadku hipoalbuminemii powinno się zawsze dążyć do zdiagnozowania tego stanu. Okres półtrwania wynosi $21 \mathrm{dni}$.

Transferryna - tansferryna jest bardziej pomocna od albumin w oznaczaniu stanu białkowego organizmu. Należy jednak pamiętać, że na jej stężenie może wpływać wiele innych czynników, na przykład niskie stężenie żelaza. Okres półtrwania wynosi 8 dni.

Prealbumina - jest dobrym wskaźnikiem stanu odżywienia, głównie ze względu na krótki okres półtrwania (2 dni) i małą pulę $w$ organizmie.
Całkowita liczba limfocytów - w niedożywieniu dochodzi do upośledzenia bariery immunologicznej. Całkowita liczba leukocytów (CLL) jest obliczana wg wzoru:

całkowita liczba leukocytów $(C L L)=(\%$ limfocytów $\times$ $\times$ liczba leukocytów)/100

Bilans azotowy - badanie polega na ocenie 24-godzinnej utraty azotu z moczem. Ujemny bilans azotowy może świadczyć o braku pokrycia zapotrzebowania na azot i jest oznaką katabolizmu.

\section{Interwencja żywieniowa}

Wybór metody leczenia żywieniowego opiera się na analizie stanu klinicznego chorego, stopnia i rodzaju niedożywienia, planowanego okresu żywienia oraz okresu stosowania żywienia (przedoperacyjne, pooperacyjne).

Bez wątpienia metodą z wyboru jest żywienie drogą przewodu pokarmowego (żywienie dojelitowe - żywienie enteralne, enteral nutrition), które obejmuje:

- podaż diety drogą doustną (w tym wzbogacenie diety kuchennej, czyli fortyfikacja diety);

- stosowanie doustnych diet przemysłowych (sip feeding);

- żywienie do żołądka (zgłębnik lub przetoka odżywcza, czyli gastrostomia);

- żywienie do jelita cienkiego (zgłębnik lub przetoka odżywcza, czyli jejunostomia).

U chorych ze wskazaniami do leczenia żywieniowego, którym nie można zapewnić odpowiedniej liczby kalorii (przynajmniej 60\% dziennego zapotrzebowania) drogą dojelitową - na przykład w przypadku przetok w górnym odcinku przewodu pokarmowego - należy rozważyć połączone żywienie pozajelitowe i dojelitowe.

Żywienie pozajelitowe stosuje się w przypadku, gdy żywienie przez przewód pokarmowy jest niemożliwe (jest to wówczas całkowite żywienie pozajelitowe) lub niewystarczające (częściowe żywienie pozajelitowe).

\subsection{Wskazania}

Leczenie żywieniowe stosujemy u chorych, u których stwierdza się (tab. IV):

1. brak możliwości włączenia diety doustnej przez ponad $7 \mathrm{dni}$; 
Tabela IV. Wskazania do leczenia żywieniowego

\begin{tabular}{ll}
\hline 1 & Brak możliwości włączenia diety doustnej przez ponad $7 \mathrm{dni}$ \\
2 & $\begin{array}{l}\text { Obecne lub zagrażające niedożywienie (BMI }<18,5 \mathrm{~kg} / \mathrm{m}^{2}, \\
\text { niezamierzona utrata masy ciała }>10 \% \mathrm{w} \text { ciągu 3-6 miesięcy } \\
\text { przed rozpoczęciem leczenia) }\end{array}$ \\
3 & $\begin{array}{l}\text { Brak możliwości utrzymania dziennego spożycia } \\
\text { pokarmów }>\text { 60\% zalecanej normy przez ponad } 10 \mathrm{dni}\end{array}$ \\
4 & $\begin{array}{l}\text { Stopień B i C w skali SGA lub wynik } \geq 3 \text { punkty w metodzie } \\
\text { przesiewowej NRS 2002 }\end{array}$ \\
\hline
\end{tabular}

Tabela V. Cechy dużego ryzyka żywieniowego

\begin{tabular}{ll}
\hline 1 & Zmniejszenie masy ciała $>10-15 \%$ w ciągu 6 miesięcy \\
2 & Wskaźnik względnej masy ciała $(\mathrm{BMI})<18,5 \mathrm{~kg} / \mathrm{m}^{2}$ \\
3 & $\begin{array}{l}\text { Stężenie albuminy w surowicy }<30 \mathrm{~g} / \mathrm{l} \text { (bez upośledzenia } \\
\text { czynności wątroby lub nerek) }\end{array}$ \\
\hline
\end{tabular}

2. obecne lub zagrażające niedożywienie $\left(\mathrm{BMl}<18,5 \mathrm{~kg} / \mathrm{m}^{2}\right.$, niezamierzona utrata masy ciała $>10 \%$ w ciągu 3-6 miesięcy przed rozpoczęciem leczenia);

3. brak możliwości utrzymania dziennego spożycia pokarmów przekraczającego 60\% zalecanej normy przez ponad $10 \mathrm{dni}$;

4. stopień B i C w skali SGA lub wynik wynoszący 3 punkty lub więcej w metodzie przesiewowej NRS 2002.

Należy zwrócić szczególną uwagę na grupę chorych o tak zwanym dużym ryzyku żywieniowym (tab. V), obejmującą osoby kwalifikowane do leczenia operacyjnego, u których stwierdza się przynajmniej jedno z wymienionych zaburzeń.

Wszyscy chorzy należący do grupy o dużym ryzyku żywieniowym powinni otrzymać leczenie żywieniowe najszybciej jak to możliwe, ale dopiero po ustabilizowaniu ich stanu metabolicznego. Intensywność interwencji żywieniowej w tej grupie w początkowym okresie (1-2 dni) nie powinna przekraczać 50\% wyliczonej podaży całkowitej na dobę. Pozwala to uniknąć ciężkiego powikłania, jakim jest zespół ponownego odżywienia (refeeding syndrome).

\subsection{Definicje}

Prekacheksja jest to wieloczynnikowy zespół towarzyszący przewlekłym chorobom, w tym również nowotworowym, charakteryzujący się: niezamierzoną utratą masy ciała poniżej 5\% w ciągu ostatnich 6 miesięcy, anoreksją, przewlekłą lub nawracającą uogólnioną reakcją zapalną.

Już na tym etapie powinno się bezzwłocznie rozpocząć interwencję żywieniową. Postępowaniem pierwszego rzutu jest poradnictwo dietetyczne oraz doustne diety przemysłowe (ONS).

\subsubsection{Zasada kompletności}

Żywienie pozajelitowe może być w pełni skuteczne tylko pod warunkiem dostarczenia organizmowi wszystkich niezbędnych składników, czyli: aminokwasów, glukozy, emulsji tłuszczowej, elektrolitów ( $\mathrm{Na}, \mathrm{K}, \mathrm{Ca}, \mathrm{Mg}, \mathrm{Cl}, \mathrm{P}$ ), pierwiastków śladowych, witamin (retinol, kalcyferol, tokoferol, witamina K, tiamina, ryboflawina, pirydoksyna, witamina B12, kwas pantotenowy, kwas foliowy, niacyna, kwas askorbinowy) i woda.

W związku z tym w praktyce przyjęto podział na:

— żywienie kompletne - dostarczające białka i energii oraz elektrolitów, witamin, pierwiastków śladowych i wody,

- żywienie niekompletne - niespełniające zasady kompletności.

\subsubsection{Czynniki immunomodulujące}

Zastosowanie substancji immunomodulujących ma na celu poprawę efektu leczenia żywieniowego poprzez wpływ na układ odpornościowy. Wynikiem postępowania immunomodulującego ma być uzupełnienie niezbędnych substancji odpowiedzialnych za funkcjonowanie bariery odpornościowej, zwalczanie stanu zapalnego i zmniejszanie efektu uogólnionej reakcji zapalnej towarzyszącej chorobom nowotworowym.

Do substancji immunomodulujących należą: glutamina, arginina, kwasy nukleotydowe, kwasy tłuszczowe omega-3. Wpływ poszczególnych substancji jest nie do końca jasny. Nie potwierdzono również negatywnego wpływu czynników immunomodulujących u chorych onkologicznych, choć zwraca się uwagę na brak potwierdzenia pozytywnego wpływu tych czynników w dużych wieloośrodkowych, randomizowanych badaniach.

Glutamina - stanowi główny rezerwuar azotu w organizmie, jest zużywana zwłaszcza przez szybko dzielące się komórki. Uważa się, że podając glutaminę chorym z chorobą nowotworową, zapewnia się prawidłowe funkcjonowanie komórkom odpornościowym i nabłonka jelitowego. W ostatnich latach pojawiły się jednak prace, w których mówi się o szkodliwości glutaminy ( $w$ badaniach in vitro) w przypadku niektórych linii raka piersi.

Arginina — jest zużywana w syntezie białek i jest niezbędna w wielu cyklach metabolicznych. Do jej niedoborów dochodzi często po dużych urazach i kacheksji. Ma korzystny wpływ na gojenie się ran.

Kwasy nukleotydowe - suplementacja kwasów nukleotydowych jest szczególnie potrzebna w stanach zwiększonego metabolizmu. Uważa się, że suplementacja nukleotydów przyspiesza regenerację kosmków jelitowych i poprawia funkcje układu immunologicznego. 
Tabela VI. Zapotrzebowanie dobowe na elektrolity

\begin{tabular}{lc}
\hline Sód & $1-2 \mathrm{mM} / \mathrm{kg}$ \\
Potas & $0,5-2 \mathrm{mM} / \mathrm{kg}$ \\
Wapń & $0,1 \mathrm{mM} / \mathrm{kg}$ \\
Magnez & $0,1-0,2 \mathrm{mM} / \mathrm{kg}$ \\
Fosfor & $0,1-0,5 \mathrm{mM} / \mathrm{kg}$ \\
\hline
\end{tabular}

\section{Wielonienasycone kwasy tłuszczowe}

Ludzki organizm nie jest w stanie syntetyzować wielonienasyconych kwasów tłuszczowych, dlatego ich suplementacja wydaje się niezbędna. Wysokie stężenia tych kwasów stwierdza się w olejach roślinnych i w tkance mięśniowej ryb morskich żywiących się algami. W organizmie ludzkim występują one w fosfolipidach błon komórkowych, są obecne w procesach wzrostu i różnicowania komórek, wpływają na procesy zapalne i immunologiczne. Kwasy tłuszczowe z grupy omega-3 ograniczają reakcję zapalną, a pochodne kwasów tłuszczowych z grupy omega-6 mają silne działanie prozapalne. Istnieją doniesienia, w których potwierdza się przeciwnowotworowe działanie wielonienasyconych kwasów tłuszczowych.

\subsection{Zapotrzebowanie}

Podaż białka u dorosłego człowieka powinna wynosić 0,8-1,5 g/kg m.c./dobę, a podaż energii - 25-35 kcal/kg m.c./dobę. Bardzo wyniszczeni chorzy powinni otrzymywać 35-45 kcal/dobę, przy podaży białka rzędu 2-3 g/kg m.c./ /dobę. Podażenergii z poszczególnych makroskładników powinna się rozkładać następująco: węglowodany - 35-50\%; tłuszcze - 30-50\%, białko - 15-20\%.

Zapotrzebowanie powinno być wyliczone na podstawie idealnej masy ciała. Najprostszy wzór na idealną masę ciała to wzrost $(\mathrm{cm})-100$.

Leczenie żywieniowe powinno być kompletne, gdyż jedynie wówczas będzie skuteczne, a wszystkie składniki prawidłowej diety, w tym elektrolity, witaminy i pierwiastki śladowe, powinny być podawane w ilościach pokrywających zapotrzebowanie dobowe (RDA — recommended daily allowance).

W przypadku żywienia dojelitowego warunek ten jest spełniony, jeżeli dieta przemysłowa jest podawana w ilości należnej na kilogram idealnej masy ciała w ciągu doby. W żywieniu pozajelitowym należy dobrać dożylną mieszaninę odżywczą (worek trójkomorowy lub przygotowany metodą mieszalnika w pracowni żywienia apteki szpitalnej).

Dobowe zapotrzebowanie na elektrolity przedstawiono w tabeli VI, natomiast na wodę (u dorosłego pacjenta) nie przekracza ono zwykle 30-40 ml/kg m.c./dobę.

\subsection{Wybór drogi leczenia żywieniowego i ogólny schemat postępowania}

Wybór drogi leczenia żywieniowego jest podstawową kwestią podczas planowania interwencji żywieniowej. Ogólny schemat postępowania ujęto na rycinie 1.
4.4.1. Leczenie żywieniowe dojelitowe

4.4.1.1. Leczenie żywieniowe dojelitowe drogą doustną

Poradnictwo dietetyczne

Poradnictwo dietetyczne to pierwszy krok w interwencji żywieniowej. Zgodnie z zaleceniami ESPEN zasadność i skuteczność stosowania poradnictwa dietetycznego u chorych onkologicznych ma siłę wiarygodności dowodów naukowych „A" według medycyny opartej na faktach (EBM - evidence based medicine). Opieka dietetyczna powinna być rutynowo włączana jako element całościowej opieki nad pacjentem chorym na nowotwór złośliwy. Prawidłowo zaplanowana porada dietetyczna to najbezpieczniejszy dla chorego, najprostszy i najtańszy sposób na utrzymanie i/lub poprawę stanu odżywienia pacjenta, możliwy do zastosowania u zdecydowanej większości chorych. Zaleca się korzystanie z poradnictwa dietetycznego na wszystkich etapach leczenia onkologicznego: od momentu rozpoznania choroby poprzez okres aktywnego leczenia (bez względu na stosowaną metodę terapii), w okresie rekonwalescencji, w profilaktyce wtórnej czy w opiece paliatywnej. Istotne jest objęcie opieką chorych po zakończonym leczeniu onkologicznym (tzw. grupy szczególne), co prawda, wolnych od nowotworu lub w okresie dłuższej remisji, ale mających głębokie niedożywienie z powodu istotnego naruszenia anatomii i/lub fizjologii przewodu pokarmowego (np. chorzy z nowotworami regionu głowy i szyi czy górnego odcinka przewodu pokarmowego). Z kolei zapobieganie otyłości i jej leczenie są szczególnie ważne jako element profilaktyki wtórnej (zmniejszenie ryzyka nawrotu) u kobiet $z$ estrogenozależnym, pomenopauzalnym rakiem piersi.

Każda porada dietetyczna musi się składać z:

- analizy dokumentacji medycznej,

- szczegółowego wywiadu żywieniowego,

- oceny stanu odżywienia,

- obliczenia zapotrzebowania na poszczególne makroi mikroskładniki diety,

- wyboru zaleceń dietetycznych (dieta oparta na zwykłych produktach, fortyfikacja diety, doustne diety przemysłowe [ONS]),

- wydania zrozumiałych dla pacjenta zaleceń, wpisu w dokumentację medyczną chorego.

\section{Wybór zaleceń dietetycznych}

Zalecenia dietetyczne zawsze muszą pokrywać zapotrzebowanie chorego na podstawowe składniki diety: białko, węglowodany, tłuszcze, witaminy, minerały i wodę. Stosowanie diet eliminacyjnych w zakresie podstawowych makroskładników jest niedopuszczalne, szczególnie diety eliminującej białko. Niemniej jednak niektóre sytuacje kliniczne wymagają modyfikacji ilości i jakości podawanych z dietą białek, tłuszczy i węglowodanów. 


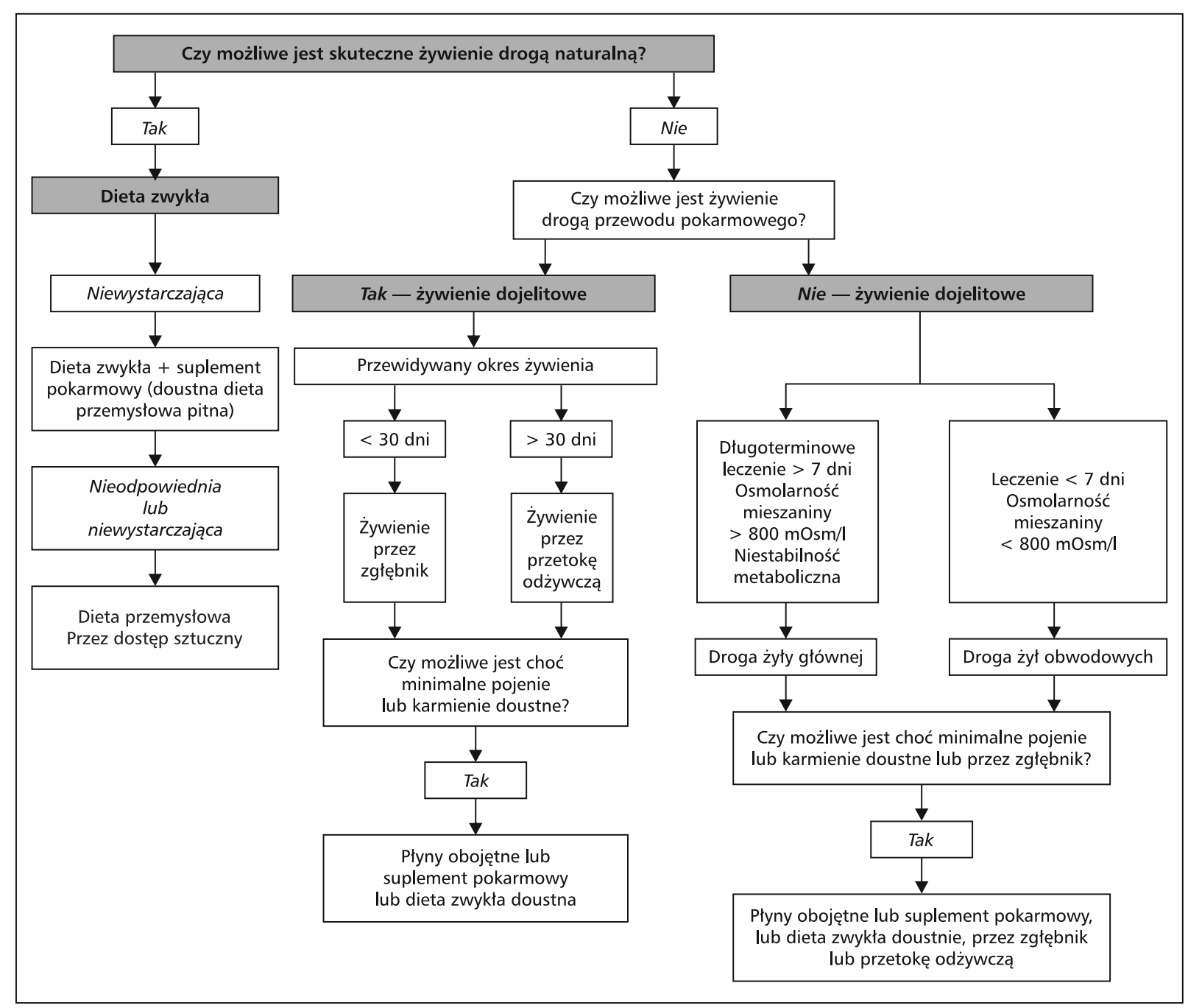

Rycina 1. Schemat postępowania przy wyborze drogi leczenia żywieniowego

Porada dietetyczna może być wydana jako dieta doustna oparta na zwykłych produktach dostępnych na rynku spożywczym lub jako dieta fortyfikowana produktami naturalnymi lub za pomocą doustnych diet przemysłowych (ONS).

\section{Fortyfikacja diety}

Fortyfikacja („wzmacnianie") żywności to sposób na zwiększenie wartości odżywczej diety poprzez:

1. dodawanie produktów naturalnych o dużej gęstości kalorycznej (np. masło, śmietanka, czekolada, miód, żółtko jaja, oleje roślinne, mleko kokosowe, gęste kasze, zmielone orzechy, mięso itp.);

2. dodawanie preparatów produkowanych przemysłowo, jedno- lub wieloskładnikowych. Preparaty jednoskładnikowe zawierają białka, węglowodany lub tłuszcze, preparaty wieloskładnikowe — różne kombinacje wymienionych makroskładników, zazwyczaj z dodatkiem witamin i minerałów. Przy fortyfikowaniu żywności często konieczna jest równoległa zmiana tekstury diety oraz objętości i częstości posiłków ze względu na ograniczony apetyt i różne dolegliwości chorego.

Fortyfikowanie żywności powinno być zawsze nadzorowane przez wykwalifikowany personel medyczny. Nieprawidłowo fortyfikowana dieta nie pokrywa zapotrzebowania na składniki pokarmowe i/lub zaburza właściwe ich proporcje, może się więc stać dietą niedoborową, a także - w przypadku nieprawidłowo zalecanych ONS — może mieć negatywny wpływ na objawy ze strony przewodu pokarmowego (np. nasilenie biegunek).

\section{Wydanie zaleceń dla pacjenta}

Wydanie zaleceń dla pacjenta powinno się odbyć w sposób zrozumiały dla niego i/lub dla jego rodziny. Należy wydać (najlepiej na piśmie) konkretne wskazówki, co chory ma jeść, jak często, jaka ma być konsystencja posiłków. Pomocne jest wydanie przykładowego jadłospisu oraz pomocy edukacyjnych. Należy pouczyć chorego, jak fortyfikować („wzmac- 
niać") dietę i jakie są zasady przyjmowania doustnych diet przemysłowych. Należy dobrać właściwy ONS do problemu klinicznego, zjakim zmaga się chory.W przypadku Szpitalnych Zespołów Żywieniowych konsultacja dietetyczna powinna zostać dołączona do dokumentacji medycznej chorego.

\section{Doustne diety przemysłowe (ONS)}

Doustne diety przemysłowe to specjalna kategoria żywności medycznej przeznaczona do żywieniowego wsparcia pacjentów niedożywionych lub zagrożonych niedożywieniem. Powinny być one wprowadzane do diety pod nadzorem wykwalifikowanego personelu medycznego (dyrektywa Unii Europejskiej 1999/21/EC 25.03.1999). Do prowadzenia takiego nadzoru medycznego (zlecanie, ale i monitorowanie efektu działania ONS) uprawnieni są lekarze, dietetycy, farmaceuci i specjalnie wykwalifikowane pielęgniarki.

Preparaty typu ONS mogą być niekompletne i kompletne pod względem składu (zawierają tylko wybrane lub wszystkie makro- i mikroskładniki diety). Wyróżniamy preparaty standardowe (odzwierciedlające skład i proporcje zwykłej diety doustnej) lub preparaty specjalne (produkowane według wymagań żywieniowych wynikających z określonych chorób — cukrzycy, niewydolności nerek etc.).

Doustne diety przemysłowe występują jako diety płynne (koktajle mleczne lub owocowe), zupy, proszki, tabletki, a także jako batoniki, ciasteczka i inne produkty. Mogą one stanowić uzupełnienie diety, a niektóre z nich mogą ją całkowicie zastąpić.

Podstawowe zalety ONS to:

1. skoncentrowanie kalorii i składników odżywczych w małej objętości,

2. wygoda stosowania: zbilansowany preparat - gotowy do użycia, nie wymaga skomplikowanych czynności kulinarnych, można go dowolnie mieszać z produktami naturalnymi, schładzać, delikatnie podgrzewać;

3. możliwość dostosowania składu preparatu do wymagań żywieniowych, jakie dyktuje choroba, na przykład preparaty niskobiałkowe dla pacjentów z niewydolnością nerek w fazie przeddializacyjnej etc.;

4. nie zawierają składników potencjalnie szkodliwych (laktoza, gluten, puryny, cholesterol); w zależności od wskazań klinicznych istnieje możliwość wyboru preparatu z błonnikiem lub bez niego;

5. są pakowane w atmosferze jałowej (sterylizowane UHT), co oznacza, że są one wolne od kontaminacji bakteryjnej.

\section{Wskazania do stosowania doustnych diet przemysłowych}

Preparaty typu ONS są wskazane u każdego chorego, który nie jest w stanie za pomocą zwykłej diety pokryć swojego indywidualnego zapotrzebowania na składniki pokarmowe. Stosowanie preparatów typu ONS jest wskazane u pacjentów, którzy spełniają dwa warunki:
1. dobrze kontrolują akt połykania (pacjent z dysfagią wymaga diet o specjalnej teksturze lub żywienie doustne nie jest w ogóle możliwe);

2. żywienie drogą przewodu pokarmowego jest możliwe; wykluczono niedrożność przewodu pokarmowego, ciężkie zapalenie lub niewydolność jelit, przetoki przewodu pokarmowego, nieopanowane wymioty.

Podstawowe makroskładniki używane do produkcji ONS są ekstrahowane ze składników naturalnych. Produkty ONS zawierają dodatek witamin, minerałów, a także niekiedy tak zwanych składników specjalnych (np. glutaminy, argininy, nukleotydy, kwasy tłuszczowe omega-3, antyoksydanty).

Z uwagi na kaloryczność wyróżnia się diety:

- hipokaloryczne $(0,5-0,9 \mathrm{kcal} / \mathrm{ml}$ diety),

- izokaloryczne (1-1,2 kcal $/ \mathrm{ml}$ diety),

- hiperkaloryczne (1,3-2,4 kcal/ml diety).

Diety hipokaloryczne są stosowane rzadko i zazwyczaj są ograniczone do przygotowania chorego do zabiegu operacyjnego (preparat węglowodanowo-elektrolitowy).

W przypadku ONS z diet wieloskładnikowych izokalorycznych korzysta się w przypadku diabetyków i osób wyniszczonych bądź długo głodzonych. W tym ostatnim przypadku diety izokaloryczne są stosowane w obawie przed rozwojem zespołu ponownego odżywienia (refeeding syndrome) w okresie adaptacji do pełnego zapotrzebowania białkowo-energetycznego. Doświadczenie kliniczne pokazuje, że diety izokaloryczne są lepiej tolerowane przez pacjentów po operacjach przewodu pokarmowego, szczególnie po gastrektomii, resekcji trzustki czy w przypadku wyłonienia ileostomii. Dieta izokaloryczna po adaptacyjnym okresie stosowania może zostać zastąpiona dietą hiperkaloryczną.

Diety hiperkaloryczne mają zastosowanie u chorych niedożywionych, ze słabym apetytem, którzy za pomocą zwykłej diety nie są w stanie pokryć swojego zapotrzebowania białkowo-energetycznego. Pewną niedogodnością w stosowaniu tych diet jest wysoka osmolarność roztworu, co może prowokować biegunki, wzdęcia czy nudności. W takim przypadku należy ściśle przestrzegać zaleceń producenta dotyczących spożywania powyższych preparatów.

Najistotniejsze jest dobranie właściwego preparatu ONS do potrzeb i możliwości przewodu pokarmowego pacjenta. Źle dobrany ONS nie tylko sprowokuje dolegliwości, ale może nasilić już istniejące niedożywienie i skutecznie zniechęcić chorego do takiego rodzaju wsparcia żywieniowego. Aktualnie dostępne są ONS przeznaczone do stosowania w: cukrzycy, niewydolności nerek, chorobie nowotworowej, patologii wątroby, trzustki i dróg żółciowych, chorobie Alzheimera, a także preparaty immunomodulujące, ONS stosowane w przygotowaniu do operacji i wiele innych. 


\subsubsection{Leczenie żywieniowe dojelitowe drogą sztuczną}

Żywienie dojelitowe przy użyciu sztucznych dostępów do przewodu pokarmowego jest wskazane u wszystkich chorych, u których nie można stosować żywienia doustnego. U chorych onkologicznych do najczęstszych przyczyn należą:

- zaburzenia połykania spowodowane obecnością guza,

- odczyny śluzówkowe i powikłania po radio- i chemioterapii głowy i szyi,

- wczesny okres pooperacyjny i leczenie powikłań po zabiegach w obrębie górnego odcinka przewodu pokarmowego.

Żywienie dojelitowe jest przeciwwskazane u chorych z niewydolnością jelit spowodowaną:

- niedrożnością przewodu pokarmowego,

- zaburzeniami wchłaniania i przetokami,

- ciężkim wstrząsem,

- niedokrwieniem jelit,

- uporczywymi biegunkami i wymiotami.

Żywienie dojelitowe można (w zależności od wskazań) podawać do żołądka lub do jelita cienkiego. Wybór rodzaju stosowanego dostępu do przewodu pokarmowego jest uzależniony od rodzaju i zaawansowania nowotworu oraz przewidywanego czasu żywienia. Dodatkowo przy wyborze drogi żywienia należy uwzględnić możliwości obsługi dostępu przez pacjenta oraz komfort stosowania tego sposobu żywienia, rodzaj planowanego leczenia onkologicznego oraz możliwości finansowania żywienia.

\section{Zgłębniki nosowo-żołądkowe i nosowe-jelitowe}

W przypadku spodziewanego czasu żywienia krótszego niż 30 dni dostępem z wyboru są zgłębniki nosowo-żołądkowe lub nosowo-jelitowe. Dzięki ich małej średnicy możliwe jest także przeprowadzenie zgłębnika pod kontrolą endoskopową przez zwężenia, powodujące nasiloną dysfagię u chorych, u których planowane jest pierwotne leczenie operacyjne po kilkutygodniowym okresie przygotowania żywieniowego.

Do żywienia przez zgłębnik należy używać płynnych, kompletnych diet przemysłowych przeznaczonych do żywienia dojelitowego. Żywienie może być podawane we wlewie grawitacyjnym lub przy użyciu specjalnie do tego celu przeznaczonych pomp perystaltycznych. Zalecane jest rozpoczęcie od wlewu $10 \mathrm{ml} /$ godzinę i stopniowe zwiększanie jego szybkości, żeby osiągnąć docelową podaż w ciągu 5-7 dni. Możliwe jest także podawanie diety w bolusach po 200-300 ml, jednakże powinno być ono stosowane tylko w przypadku zgłębników założonych do żołądka.

Ograniczenia stosowania zgłębników są związane z: ich średnicą, a co za tym idzie - możliwością zatkania cewnika przy nieprawidłowym dbaniu o utrzymanie jego drożności; możliwością przypadkowego usunięcia zgłębnika przez chorego; koniecznością podaży innych przyjmowanych przez pacjenta leków w formie płynnej lub odpowiednio przygotowanej zawiesiny.

\section{Gastrostomia}

Gastrostomia jest bezpośrednim dostępem do żołądka zakładanym metodami chirurgicznymi (klasycznie lub laparoskopowo) lub endoskopowymi (PEG — percutaneous endoscopic gastrostomy). Ze względu na mniejszą inwazyjność oraz łatwiejszą pielęgnację PEG uznawany jest za dostęp z wyboru. Zarówno w przypadku zakładania gastrostomii endoskopowej, jaki otwartej zaleca się używanie gotowych zestawów. Nie należy stosować drenów przeznaczonych do innych celów medycznych.

Wskazaniem do założenia gastrostomii jest spodziewana konieczność żywienia przez okres dłuższy niż 30 dni.

Gastrostomia endoskopowa jest przeciwwskazana u chorych z:

- poważnymi zaburzeniami krzepnięcia

- rozsiewem śródotrzewnowym nowotworu,

- zapaleniem otrzewnej i nasilonym wodobrzuszem,

- interpozycją narządów jamy brzusznej.

Do najczęstszych powikłań gastrostomii należą:

- zakażenia rany i okolicy gastrostomii,

- niedrożność cewnika,

— przeciek i nieszczelność wokół gastrostomii,

- wypadnięcie gastrostomii,

- wrośnięcie grzybka PEG (buried bumper syndrome).

Żywienie do gastrostomii może być prowadzone metodą bolusów 5-6 razy na dobę po 200-300 ml, pod kontrolą zalegania żołądkowego, mikrobolusów w porcjach po 50-100 ml lub wlewu ciągłego z prędkością wlewu 20-30 ml/godzinę.

U chorych żywionych do gastrostomii zalecane jest stosowanie diet przemysłowych. Możliwe jest także podawanie kuchennej diety zmiksowanej, należy jednak pamiętać, że jej stosowanie jest trudniejsze, obarczone dużym ryzykiem błędu oraz nie można precyzyjnie określić wartości odżywczej tak przygotowanej mieszaniny. Nie można także rozliczyć takiego leczenia w ramach refundacji przez Narodowy Fundusz Zdrowia.

\section{Mikrojejunostomia}

Mikrojejunostomia jest stosowana u chorych wymagających żywienia dojelitowego przez okres dłuższy niż 30 dni. Powinna być dostępem z wyboru w sytuacjach, gdy założenie gastrostomii jest niemożliwe lub przeciwwskazane, a także jeśli planowane jest wykorzystanie żołądka jako narządu do odtworzenia ciągłości przewodu pokarmowego w chirurgii przełyku i połączenia żołądkowo-przełykowego. Mikrojejunostomię można założyć metodą klasyczną lub laparoskopową, a także przy użyciu gotowych zestawów do igłowej jejunostomii cewnikowej. 
Do jelita cienkiego mogą być podawane wyłącznie sterylne diety przemysłowe, dostosowane składem i osmolarnością do fizjologii jelita cienkiego. Diety te powinny być podawane wyłącznie we wlewach kroplowych grawitacyjnych lub przy użyciu pomp perystaltycznych, z początkową szybkością wlewu $10 \mathrm{ml} /$ godzinę, stopniowo zwiększaną w ciągu 5-7 dni. Podanie diety w bolusie lub zbyt szybkim wlewie może powodować nietolerancję żywienia pod postacią biegunki, bólów brzucha i wzdęć.

\subsubsection{Leczenie żywieniowe pozajelitowe}

W przypadku braku możliwości zastosowania leczenia żywieniowego drogą przewodu pokarmowego leczenie to musi zostać podane drogą dożylną. Żywienie pozajelitowe może być jedynym sposobem dostarczania substancji odżywczych — całkowite żywienie pozajelitowe (TPN — total parenteral nutrition) lub może być stosowane jako dodatek do żywienia dojelitowego lub diety doustnej — wówczas jest to częściowe żywienie pozajelitowe. W każdym przypadku należy wykorzystać metodę jednego worka (all-in-one).

Metoda jednego worka zakłada podawanie wszystkich składników zmieszanych w jednym pojemniku. Pozwala to na lepszą tolerancję żywienia, zmniejszenie liczby zakażeń i obniżenie kosztów.Żywienie metodąjednego worka może być prowadzone przy użyciu mieszanin sporządzonych na oddziałach przezzmieszanie wszystkich półpreparatów, mieszanin przygotowanych waptekach szpitalnych w technologii mieszalnika lub użycie worków wielokomorowych (trójkomorowych).

Żywienie pozajelitowe może być prowadzone przy użyciu: - cewnika, którego końcówka znajduje się w żyle centralnej, zazwyczaj w miejscu połączenia żyły głównej górnej i prawego przedsionka — tak zwane żywienie pozajelitowe drogą centralnąi

- kaniuli założonej do żyły obwodowej, zazwyczaj przedramienia - tak zwane żywienie pozajelitowe drogą obwodowąi

- przetoki tętniczo-żylnej używanej do hemodializy lub utworzonej wyłącznie w celu żywienia pozajelitowego u pacjentów, u których założenie cewnika centralnego nie jest możliwe;

- portu naczyniowego wszczepionego pod skórę klatki piersiowej (TID — totally implanted device).

Czas żywienia drogą żył obwodowych nie powinien przekraczać 7 dni. W innych przypadkach stosuje się je tylko w przypadku braku możliwości wytworzenia dostępu centralnego. Żywienie pozajelitowe prowadzi się sposobem ciągłym (wlew przez 22-24 godz. w ciągu doby) lub w schemacie cyklicznym (12-18 godz. w ciągu doby).

Powikłania żywienia pozajelitowego mogą być związane z dostępem żylnym (techniczne i infekcyjne) oraz zaburzeniami metabolicznymi. Najczęstsze są zaburzenia glikemii oraz wodno-elektrolitowe. Groźnym powikłaniem może być zespół ponownego odżywienia (refeeding syndrome).
Stosowanie zasad leczenia żywieniowego pozwala uniknąć powikłań.

\subsection{Refeeding syndrome}

Zespół ponownego odżywienia lub szoku pokarmowego (refeeding syndrome) to zagrażający życiu zespół zaburzeń wielonarządowych ze strony układu sercowo-naczyniowego, płuc, wątroby, nerek, układu nerwowo-mięśniowego oraz metabolicznych i hematologicznych na skutek niewłaściwej resuscytacji żywieniowej u osób poważnie niedożywionych. U podłoża zaburzeń metabolicznych zespołu leży nagły dopływ dużej ilości glukozy i innych źródeł energii. Wiodący wpływ na rozwój tych zaburzeń mają hipofosfatemia i ogólnoustrojowy niedobór fosforanów, ponieważ fosfor jest substratem niezbędnym do reakcji syntezy adenozynotrójfosforanu (ATP — adenosine triphosphate) katalizowanej przez enzym - syntazę ATP. Brak energii ogranicza wydolność pompy sodowo-potasowej (ATP-aza $\mathrm{Na}^{+} / \mathrm{K}^{+}$), odpowiedzialnej za utrzymanie potencjału błonowego. Hipoalbuminemia, wynikająca z przewagi degradacji albuminy nad jej syntezą, skutkuje przesunięciami płynowymi i nadmierną retencją płynów w organizmie. Pojawiają się objawy kliniczne niewydolności wielonarządowej. Występuje niewydolność krążenia, pojawiają się zaburzenia rytmu serca, wzrasta niebezpieczeństwo komorowych zaburzeń rytmu i nagłej śmierci sercowej. Niedobór energii powoduje niedomogę ze strony przepony i innych mięśni wspierających oddychanie, czego wyrazem jest niewydolność układu oddechowego. W obrazie krwi pojawia się anemia, wynikająca z niedoboru żelaza i nadmiernego rozpadu erytrocytów. Dochodzi do obniżenia naturalnej odporności, co podnosi ryzyko powikłań infekcyjnych. Z powodu degradacji białek maleje siła i wydolność mięśni oraz dochodzi do zaniku tkanki mięśniowej. Ze strony centralnego układu nerwowego mogą się pojawić objawy encefalopatii Wernickego. Objawy niewydolności krążeniowo-oddechowej mogą doprowadzić do zgonu.

Wysokie ryzyko wystąpienia zespołu obserwuje się u osób, które utraciły więcej niż $10 \%$ masy ciała w okresie 1-3 miesięcy, ważących poniżej 70-80\% należnej masy ciała, u których tkanki mięśniowej ubywa w sposób widoczny, skarżących się na przewlekle kłopoty w przełykaniu. Do tej grupy należą także cierpiący na uporczywe nudności, wymioty czy biegunki z następowym ograniczeniem przyjmowania pokarmów doustnie. Głodzenie w okresie przekraczającym 7 dni czy niedostateczna podaż witamin, mikroelementów i elektrolitów (m.in. nieadekwatna do potrzeb ich ilość), terapia żywieniowa dojelitowa lub pozajelitowa trwająca powyżej 10 dni to czynniki, które także zwiększają prawdopodobieństwo wystąpienia zespołu ponownego odżywienia.

U osób dorosłych z wysokim ryzykiem wystąpienia tego zespołu leczenie żywieniowe rozpoczyna się od oszacowania dobowego zapotrzebowania na energię w zakre- 
Tabela VII. Badania laboratoryjne w trakcie żywienia pozajelitowego

\begin{tabular}{lccc}
\hline Badanie & Przed leczeniem & W pierwszych dniach leczenia & W okresie stabilizacji \\
\hline Gazometria (w przypadku żywienia pozajelitowego) & Tak & Tak & $1-2 \times$ w tygodniu \\
Jonogram: $\mathrm{Na}, \mathrm{K}, \mathrm{Mg}, \mathrm{Cl}, \mathrm{P}$ & Tak & Tak & W moczu - codziennie \\
Glikemia & Tak & Tak & $1 \times$ w tygodniu \\
Białko całkowite, albuminy & Tak & & $1 \times$ w tygodniu \\
Mocznik, kreatynina & Tak & Tak & $1 \times$ w tygodniu \\
AspAT, AlAT, GGTP, bilirubina & Tak & & $1 \times$ tygodniu \\
Morfologia, układ krzepnięcia & Tak & & $1 \times$ w tygodniu \\
CRP & Tak & Tak & \\
Triglicerydy, cholesterol & Tak &
\end{tabular}

AspAt (aspartate aminotransferase) — aminotransferaza asparaginianowa; AIAT (alanine aminotransferase) — aminotransferaza alaninowa; GGTP (gamma-glutamyltranspeptidase) - gamma-glutamylotranspeptydaza; CRP (C-reactive protein) - białko C-reaktywne

sie 25-75\%, czyli 5-20 kcal/kg/dobę. Zwiększenie wartości energetycznej żywienia następuje w okresie 3-10 dni o 10-25\% dziennie, czyli o około 200-250 kcal dziennie. Gdy pojawią się objawy zespołu ponownego odżywienia, należy zmniejszyć lub wstrzymać leczenie żywieniowe do czasu ich ustąpienia. Wznowienie leczenia powinno się rozpocząć od połowy dawki wyjściowej. W ramach profilaktyki refeeding syndrome należy pamiętać o dostarczaniu witamin (bardzo ważne witaminy z grupy B, w szczególności witamina B1) i mikroelementów, potrzebie pilnego nadzoru nad gospodarką płynową w ujęciu dobowym, monitorowaniu pracy serca i obserwacji wahań masy ciała pacjenta.

W zapobieganiu i leczeniu zespołu ponownego odżywienia bardzo dużą rolę odgrywa prawidłowe funkcjonowanie multidyscyplinarnych zespołów żywieniowych.

\subsection{Monitorowanie leczenia żywieniowego}

Monitorowanie stanu chorego jest niezbędne zarówno przed leczeniem żywieniowym, jak i w jego trakcie. Monitorowanie stanu biochemicznego ma szczególne znaczenie w przypadku leczenia pozajelitowego. Zakres kontroli — badań antropometrycznych i biochemicznych - musi być zawsze uzależniony od stanu chorego, schorzeń towarzyszących (cukrzyca, niewydolność wątroby, nerek), ciężkości choroby podstawowej i obecności powikłań.

\subsubsection{Monitorowanie leczenia żywieniowego przed leczeniem}

Przed rozpoczęciem leczenia oprócz oceny stanu odżywienia należy określić stan biochemiczny ustroju (tab. VII).

\subsubsection{Monitorowanie leczenia żywieniowego w trakcie leczenia}

W trakcie leczenia żywieniowego chory podlega codziennej kontroli klinicznej, w ramach której prowadzony jest bilans płynów, pomiar temperatury i wagi ciała. Schemat
Tabela VIII. Przykładowe metody monitorowana efektu terapii żywieniowej

\begin{tabular}{ll}
\hline Metody & BMI \\
antropometryczne & $\begin{array}{l}\text { Pomiar fałdu tłuszczowego } \\
\text { Analiza bioimpedancyjna }\end{array}$ \\
\hline Badania laboratoryjne & $\begin{array}{l}\text { Albuminy, białko całkowite, transferryna, } \\
\text { prealbuminy } \\
\text { Bilans azotowy }\end{array}$ \\
\hline
\end{tabular}

rutynowych badań laboratoryjnych u chorych w trakcie leczenia przedstawiono $w$ tabeli IV.

Osobnym zadaniem jest codzienna kontrola i monitorowanie dostępów dożylnych i/lub dojelitowych (wkłucia obwodowe i centralne, porty naczyniowe, PEG, jejunostomie i inne). Opis stanu tych dostępów powinien być na bieżąco opisywany w dokumentacji medycznej. Prowadzenie dokumentacji dotyczącej wkłucia centralnego jest obowiązkowe w przypadku prowadzenia żywienia pozajelitowego w szpitalu w ramach refundacji przez Narodowy Fundusz Zdrowia.

Monitorowanie stanu chorego jest niezbędne do określenia efektu terapii oraz wystąpienia ewentualnych powikłań. Stosuje się badanie przedmiotowe, metody antropometryczne, badania laboratoryjne (tab. VIII).

Monitorowanie umożliwia rozpoznanie osiągnięcia zamierzonego celu terapii i może być wskazaniem do zmiany zaleceń lub nawet zakończenia leczenia.

\section{Sytuacje szczególne 5.1. Nowotwory głowy i szyi}

$\mathrm{U}$ wielu chorych z rozpoznaniem nowotworu regionu głowy i szyi już w momencie diagnozy i podjęcia decyzji o leczeniu onkologicznym występują pierwsze symptomy pogorszenia się stanu odżywienia - głównie utrata masy ciała. Niedożywienie stwierdza się nawet u $80 \%$ chorych przyjmowanych na oddziały onkologiczne. 
Mimo że leczenie żywieniowe jest w większości przypadków leczeniem wspomagającym, a nie swoistą terapią danej choroby, zapobiega niekorzystnym skutkom głodzenia, dlatego też jest jednym z elementów postępowania terapeutycznego i wymaga właściwego z nim zintegrowania.

Jak podano w wytycznych ESPEN, nie ma wskazań do rutynowego prowadzenia żywienia dojelitowego u chorych z nowotworem regionu głowy i szyi w trakcie radioi chemioterapii, jeżeli nie stwierdza się istniejących lub zagrażających zaburzeń połykania, ponieważ nie wpływa to ani na leczenie, ani na zmniejszenie działań niepożądanych z nim związanych. Interwencja żywieniowa jest konieczna również zawsze wtedy, gdy codzienna podaż składników odżywczych nie przekracza przynajmniej $60 \%$ dziennego zapotrzebowania przez okres dłuższy niż 10 dni.

Zaleca się natomiast stosowanie poradnictwa żywieniowego i doustne diety przemysłowe w celu zwiększenia ilości przyjmowanego pokarmu oraz zapobiegania związanej z leczeniem przeciwnowotworowym utracie masy ciała. Decyzja o interwencji żywieniowej powinna nastąpić w przypadku stwierdzenia wskazań jak w punkcie 4.

Według zaleceń ESPEN u chorych na nowotwory preferuje się żywienie drogą przewodu pokarmowego, jeśli jest ono tylko możliwe, także za pomocą ONS.

Gdy naturalne odżywienie doustne jest niewystarczające lub niemożliwe (np. z powodu zaburzeń połykania u chorych z nowotworem głowy i szyi lub przełyku), można zastosować żywienie przy użyciu zgłębników do żołądka, dwunastnicy, jelita cienkiego lub za pomocą przetok odżywczych: gastro- lub jejunostomii. Przetoki odżywcze stosuje się, gdy założenie sondy nie jest możliwe (dosyć często u chorych z zapaleniem błony śluzowej jamy ustnej i przełyku wskutek radioterapii) lub gdy planuje się prowadzenie żywienia przez dłuższy czas. Obecnie postępowaniem z wyboru jest gastrostomia odżywcza wytworzona drogą endoskopową, czyli PEG. W wybranych sytuacjach chorzy są kwalifikowani do leczenia żywieniowego pozajelitowego.

Ocena stanu odżywienia i decyzja o ewentualnej interwencji jest obowiązkiem każdego lekarza prowadzącego terapię chorych z nowotworami głowy i szyi. Wczesne decyzje korzystnie wpływają na poprawę jakości życia chorych i wyniki stosowanego leczenia.

\subsection{Popromienne zapalenie jelit}

Radioterapia w obrębie jamy brzusznej lub miednicy mniejszej może powodować istotne powikłania żołądkowo-jelitowe. W ostatnich latach stwierdza się częstsze występowanie enteropatii popromiennej, co niewątpliwie jest wynikiem stosowania radioterapii jako części składowej w multidyscyplinarnej terapii nowotworów. Oszacowanie częstości występowania tego powikłania jest trudne, po- nieważ najłagodniejsze jego rodzaje nie są rozpoznawane klinicznie, a późniejsze i poważniejsze pojawiają się po wielu latach od zakończenia radioterapii, kiedy pacjenci są już leczeni w innych ośrodkach bądź podlegają operacjom w trybie nagłym. Ogólnie uważa się, że różnego stopnia enteropatia popromienna może dotyczyć od $2 \%$ do $30 \%$ pacjentów podanych radioterapii.

Objawy enteropatii popromiennej zazwyczaj ustępują z czasem, a leczeniem jest zwykle płynoterapia lub żywienie pozajelitowe, które umożliwiają wyłączenie przewodu pokarmowego. W podostrym wariancie tego powikłania obowiązują dwa sposoby leczenia, zależne od zaawansowania schorzenia:

1. Miejscowa enteropatia popromienna: leczenie farmakologiczne z płynoterapią lub żywieniem pozajelitowym (zależnie od czasu trwania interwencji); w przypadku braku poprawy interwencja chirurgiczna.

2. Rozlana enteropatia popromienna: w pierwszej kolejności próba żywienia pozajelitowego. Jeśli objawy ustępują, należy rozważyć domowe żywienie pozajelitowe (> 4-6 miesięcy). Zabieg chirurgiczny należy rozważy tylko wtedy, jeżeli objawy nie ustępują lub jeśli są obecne podczas żywienia doustnego/dojelitowego, które zostało włączone po okresie stosowania żywienia pozajelitowego.

U niektórych pacjentów rozwija się zespół zaburzeń przewlekłych. W tych przypadkach obowiązuje inne podejście: wielu pacjentów z tej grupy musi być poddana operacji, gdyż niedrożność lub zwężenie jelit na tym etapie są nieodwracalne. Coraz szerzej wykorzystywaną alternatywą jest ciągłe żywienie pozajelitowe, dzięki któremu skutecznie eliminuje się konieczność kolejnych doraźnych operacji, w wielu przypadkach pozwalając ich uniknąć, jak również umożliwia się precyzyjne przygotowanie pacjenta do zabiegu, jeżeli jest on konieczny. W Polsce domowe żywienia pozajelitowe prowadzą wyspecjalizowane ośrodki w ramach kontraktu z Narodowym Funduszem Zdrowia.

\section{3. Żywienie podczas chemioterapii}

W większości przypadków podczas leczenia systemowego zapotrzebowanie energetyczne może być zaspokajane drogą doustną. Obecność objawów i działań niepożądanych, zarówno napotykanych w trakcie chemioterapii, jak i wynikających z przebiegu choroby, sprawia, że chorzy są szczególnie podatni na wystąpienie niedoborów żywieniowych.

\subsubsection{Zalecenia dietetyczne w zależności od objawów} Nudności: małe i częste posiłki, raczej zimne, słabo pachnące, lekkostrawne. Najistotniejsza jest podaż płynów z elektrolitami, które częściowo można ukryć w pokarmach. Pokarmy zalecane: zupy i zupy krem, koktajle owocowe i owocowo-mleczne, musy z warzyw i owoców, soki roz- 
cieńczane wodą, galaretki, budynie, lody, sorbety, omlety, naleśniki, twarożki i drobne kasze.

Biegunka: zalecana jest dieta BRAT (B - banany mało dojrzałe, R - ryż biały, A - apple - jabłka pieczone/gotowane, $\mathbf{T}$ - tosty pszenne) i doustne uzupełnianie wody oraz elektrolitów. Inne produkty zapierające: gotowane warzywa korzeniowe, jajka na twardo, chude mięsa gotowane, napar i owoce czarnych jagód, gorzka czarna herbata, sok z marchwi.

Zaparcia: kluczowe jest określenie przyczyny zaparcia (wykluczenie niedrożności lub niedrożności przepuszczającej przewodu pokarmowego) i czasu jego trwania. Przykładem mogą być zaparcia po inhibitorach receptora 5HT-3, które mijają samoistnie po 2-3 dniach i nie wymagają interwencji dietetycznej. Z kolei zaparcia po opioidach wymagają nie tylko pomocy dietetycznej, ale i leczenia farmakologicznego.

\subsubsection{Zalecenia dotyczące zastosowania} odpowiedniej diety

\subsubsection{Dieta wysokobłonnikowa}

Przed wprowadzeniem diety wysokobłonnikowej należy uregulować pasaż przewodu pokarmowego (nawodnienie, leki przeczyszczające, lewatywy, ręczne wydobycie stolca). Diety wysokobłonnikowe (pełne ziarna, warzywa nieskrobiowe, owoce zawierające sorbitol, orzechy, fermentowany nabiał) zawsze wymagają równolegle odpowiedniej podaży płynów (6-8 szkl./dobę).

\subsubsection{Dieta bezlaktozowa}

Nie ma wskazań do rutynowego stosowania diet bezlaktozowych u chorych leczonych onkologicznie. Nietolerancja laktozy, która powstaje na skutek leczenia cytostatykami lub na skutek radioterapii, ma charakter wtórny i związany z uszkodzeniem funkcji nabłonka jelitowego (niedostatek w produkcji laktazy, enzymu hydrolizującego laktozę - cukier mleczny). Objawy to nudności, wzdęcia i biegunki. W przypadku gdy zachodzi konieczność wyłączenia laktozy $z$ diety, należy utrzymać dietę bezlaktozową jeszcze przez 6-10 tygodni po zakończeniu leczenia.

Szczegółowe wskazania do eliminacji produktów mlecznych z diety to:

— istniejąca uprzednio nietolerancja laktozy (ok. 20\% populacji osób w wieku podeszłym w Polsce);

- chemioterapia oparta na lekach takich jak: lapatynib, kapecytabina, 5-fluorouracyl, irynotekan, topotekan, inhibitory kinaz tyrozynowych (erlotynib, gefytynib, sorefenib, sunitynib), immunoterapia (ipilimumab, niwolumab); rzadko eliminacji laktozy wymagają pacjenci leczeni taksanami czy metotreksatem;

- chemioterapia wysokodawkowa w przebiegu nowotworów krwi i układu chłonnego;

- radioterapia obszarów jamy brzusznej i miednicy (m.in. rakżołądka, odbytnicy, trzustki, szyjki macicy, prostaty).

\subsubsection{Dieta bezglutenowa}

Za wyjątkiem pacjentów z uprzednio rozpoznaną celiakią nie ma wskazań do stosowania diet bezglutenowych w onkologii. Należy podkreślić, że produkty zawierające gluten (pszenica, żyto, jęczmień, owies) to nie tylko źródło węglowodanów, ale również białka, całej grupy witamin B, witaminy E, żelaza, magnezu, potasu, wapnia, selenu, cynku i wielu innych składników diety. Dieta bezglutenowa bywa stosowana w niektórych przypadkach ciężkiego popromiennego zapalenia jelit (głównie radioterapia z powodu raka szyjki macicy) lub ciężkiego zapalenia jelit po chemioterapii (przeszczepienie komórek macierzystych szpiku kostnego) i wpływa pozytywnie na opanowanie biegunki, niemniej jednak brak badań klinicznych, których wyniki jednoznacznie potwierdzałyby zasadność takiego postępowania w praktyce klinicznej.

Zarówno dieta bezlaktozowa, jak i bezglutenowa wymagają zbilansowania przez wykwalifikowanego dietetyka.

\subsubsection{Wskazania do suplementacji związków aktywnych}

Zgodnie z zaleceniami zarówno ESPEN, National Institute for Health and Clinical Excellence (NICE), jak i większości towarzystw dietetycznych na świecie nie ma wskazań do rutynowej suplementacji witamin czy minerałów u pacjentów chorujących na nowotwór złośliwy. Suplementację należy wdrożyć, jeśli mamy do czynienia z:

1. udokumentowanym niedoborem składnika (oznaczenie stężenia we krwi lub typowe kliniczne cechy niedoboru) — na przykład niedobór wapnia i witaminy D3 w osteoporozie czy niedokrwistość z niedoboru żelaza;

2. sytuacją kliniczną, która z pewnością do niedoboru doprowadzi - na przykład stanem po całkowitej gastrektomii i rozwojem niedoboru witaminy B12 (brak czynnika wewnętrznego) lub zespołami złego wchłaniania wymagającymi suplementacji wielu składników witaminowo-mineralnych.

\subsection{Leczenie żywieniowe u chorych poddawanych leczeniu operacyjnemu 5.4.1. Przygotowanie przedoperacyjne 5.4.1.1. Pacjenci z niedożywieniem}

Niedożywienie jest istotnym czynnikiem ryzyka powikłań leczenia chirurgicznego, pomimo to jest ono rozpoznawane o wiele rzadziej niż występuje.

Odsetek niedożywienia u pacjentów oczekujących na operację z powodów onkologicznych różni się w zależności od miejsca występowania nowotworu. Niedożywienie częściej towarzyszy nowotworom górnego odcinka przewodu pokarmowego oraz rakowi trzustki i dróg żółciowych aniżeli nowotworom jelita grubego. W każdym przypadku o potrzebie interwencji żywieniowej i szczegółach z nią związanych decyduje w podobny 
sposób wynik rzetelnie przeprowadzonej oceny stanu odżywienia.

Bez względu na sposób oceny stanu odżywienia podnosi się wartość interwencji żywieniowej przed operacją u wszystkich chorych z chorobą nowotworową, u których stwierdzono głębokie niedożywienie (tab. IV i V).

Interwencja żywieniowa poprawia wyniki leczenia (zarówno doraźne, jak i odległe) oraz poprawia jakość życia. Brak poprawy stanu odżywienia pacjenta w ocenie klinicznej i w badaniach laboratoryjnych zazwyczaj przemawia za głębokim zaawansowaniem choroby nowotworowej, podaje w wątpliwość celowość leczenia z resekcją guza pierwotnego oraz wskazuje na potrzebę postępowania zachowawczego. U chorych średnio niedożywionych i tych zagrożonych niedożywieniem uzyskuje się dzięki wsparciu żywieniowemu zazwyczaj zmniejszenie ryzyka różnych powikłań, ale korzyści z tego działania nie są tak spektakularne i jednoznaczne jak w grupie z głębokim niedożywieniem. Niemniej jednak przyjęto za celowe stosowanie wsparcia żywieniowego w okresie przed operacją u chorych z chorobą nowotworową średnio niedożywionych oraz o wysokim ryzyku wystąpienia niedożywienia. Pomimo niejednoznacznych opinii o klinicznych korzyściach ze stosowania immunomodulacji w okresie przed operacją stosuje się substancje immunomodulujące jako dodatek do preparatów leczenia żywieniowego w tym okresie, opierając się na doniesieniach wskazujących jednoznacznie na celowość takiego działania.

Powszechnie uznane za bezpieczne i szeroko zalecane postępowanie według programu Enhanced Recovery After Surgery (ERAS) zakłada potrzebę oceny stanu odżywienia pacjenta przed operacją oraz interwencję żywieniową w przypadku stwierdzenia u niego niedożywienia. Dobrze przygotowanym do operacji pacjentom, u których nie występują obciążenia towarzyszące (jak cukrzyca), w programie ERAS zaleca się podaż płynów z węglowodanami doustnie w objętości $400 \mathrm{ml}$ w okresie do 2 godzin przed operacją. Postępowanie to jest profilaktyką pooperacyjnej insulinooporności, hiperglikemii, nadmiernej utraty białek i masy ciała. Służy zachowaniu właściwej kondycji tkanki mięśniowej, redukuje uczucie niepokoju po operacji, zmniejsza ryzyko nudności i wymiotów. Zamiennie do podaży węglowodanów doustnie można podać 20-procentową glukozę dożylnie w dawce $5 \mathrm{mg} / \mathrm{kg}$.

\subsubsection{Pacjenci bez niedożywienia}

U chorych niewykazujących cech niedożywienia, a zatem zgodnie z międzynarodowymi wytycznymi — niekwalifikujących się do przedoperacyjnego intensywnego leczenia żywieniowego, postępowanie w czasie oczekiwania na zabieg operacyjny powinno być skierowane na zapobieganie pogorszeniu stanu odżywienia oraz przygotowanie stanu metabolicznego chorego na leczenie.

\subsection{2. Żywienie pooperacyjne}

W przypadku chorych prawidłowo odżywionych opieka pooperacyjna powinna być prowadzona zgodnie z zasadami ERAS, a więc postępowaniem z wyboru u chorych bez cech niedożywienia powinno być jak najwcześniejsze włączenie doustnego żywienia oraz dążenie do jak najszybszego pokrycia powyżej $60 \%$ zapotrzebowania energetycznego.W przypadku braku możliwości podawania żywienia doustnego zalecanym dostępem w żywieniu pooperacyjnym powinny być zgłębniki lub odżywcze przetoki jelitowe ze względu na potencjalnie wyższe ryzyko powikłań związanych z prowadzeniem żywienia przez centralne dostępy naczyniowe. Żywienie powinno być prowadzone przy użyciu diet przemysłowych.

\subsubsection{Leczenie powikłań}

Włączenie leczenia żywieniowego powinno być rozważane w sytuacji, gdy po zabiegu operacyjnym dochodzi do wystąpienia któregoś ze wskazań (tab. IV i V).

Sytuacją szczególną do zastosowania terapii żywieniowej jest sytuacja, gdy dochodzi do rozpoznania przetoki przewodu pokarmowego. Występowanie przetok wiąże się z ryzykiem wystąpienia następnych powikłań, na przykład posocznicy, ciężkiego stanu chorego, a nawet zgonu. Najczęstszą przyczyną wystąpienia przetoki są następstwa zabiegów chirurgicznych przewodu pokarmowego i jamy brzusznej. Mogą one także występować samoistnie, w przypadku progresji zmian nowotworowych, chorób zapalnych i innych. Z uwagi na towarzyszące im problemy kliniczne i obraz kliniczny ich leczenie odbywa się w większości na oddziałach chirurgicznych.

Szczegółowe zasady rozpoznawania i leczenia przetok przewodu pokarmowego u chorych leczonych z powodu nowotworów zostały ujęte w rekomendacjach Polskiego Towarzystwa Chirurgii Onkologicznej.

\subsubsection{Wsparcie żywieniowe po leczeniu}

Po zabiegach resekcyjnych w zakresie okrężnicy lub odbytnicy poza pojedynczymi sytuacjami, szczególnie w przypadku powikłań, chorzy nie wymagajążadnej specjalistycznej interwencji żywieniowej. Zalecenie prawidłowo skomponowanej diety przez dietetyka jest zupełnie wystarczające.

Po zabiegach resekcyjnych w obrębie przełyku, żołądka i trzustki pacjenci wymagają porady dietetycznej właściwie w każdym przypadku. Jest to szczególnie istotne u pacjentów po resekcji przełyku lub żołądka, gdyż u tych chorych często rozwijają się uporczywe biegunki lub zespół poposiłkowy (dumping syndrome).

U pacjentów poddanych rozległym zabiegom resekcyjnym może się rozwinąć zespół krótkiego jelita (SBS — short bowel syndrome). Obejmuje on sytuacje, gdy resekcja jelita cienkiego prowadzi do takiego zmniejszenia przyswajania składników odżywczych, które jest niewystarczające do utrzymania integralności i funkcji całego organizmu. Mini- 
malna długość jelita cienkiego zapewniająca odpowiednie wchłanianie jest różna i zależy od ogólnego stanu i zdolności wchłaniania pozostałego odcinka jelita, niemniej uważa się, że aby uniknąć permanentnego żywienia pozajelitowego u pacjentów, u których wyłoniono ileostomię końcową, długość pozostawionego jelita cienkiego musi wynosić co najmniej $100 \mathrm{~cm}$, a w przypadku zespolenia czczo-poprzeczniczego - co najmniej $65 \mathrm{~cm}$. W każdym innym przypadku przeżycie jedynie na diecie doustnej nie jest możliwe.

Kliniczne objawy SBS to: biegunka, stolce tłuszczowe, utrata masy ciała, odwodnienie oraz niedożywienie, wynikające z niedostatecznego wchłaniania makroskładników odżywczych, witamin, płynów, elektrolitów i pierwiastków śladowych. Skutkiem tego są hipowolemia, hipoalbuminemia i kwasica metaboliczna.

Powikłania SBS obejmują między innymi: nadmierne wydzielanie kwasu solnego, kwasicę D-mleczanową, kamicę nerkową oraz nefropatię szczawianową, kamicę żółciową i zaburzenia czynności wątroby.

Leczenie metaboliczne i żywieniowe w SBS dzieli się na trzy okresy:

- bezpośredni okres pooperacyjny,

- okres adaptacji jelita,

- długotrwałe leczenie.

Postępowanie natychmiast po operacji obejmuje:

- uzupełnianie strat płynów i elektrolitów,

- zmniejszanie wydzielania kwasu solnego, hamowanie czynności wydzielniczej i motorycznej przewodu pokarmowego,

- żywienie pozajelitowe.

Utratę dużych objętości płynów spowodowaną biegunką, wydzielaniem przez stomię lub odsysaniem przez zgłębnik nosowo-żołądkowy należy starannie monitorować i wyrównywać — podaż płynów powinna bilansować wszystkie straty i utrzymywać diurezę dobową powyżej $1000 \mathrm{ml}$. Dalsze postępowanie zależy od stanu pacjenta.

Żywienie pozajelitowe należy rozpocząć wcześnie w celu resuscytacji płynowej oraz w celu zapobiegania niedożywieniu lub leczenia go. Żywienie dojelitowe należy zwiększać powoli, zależnie od ilości wydalanego stolca. W ciężkich postaciach SBS do końca życia należy prowadzić przewlekłe żywienie pozajelitowe wraz z leczeniem zmniejszającym wydzielanie, aby zapobiec postępującemu niedożywieniu oraz potencjalnie śmiertelnym niedoborom wody i elektrolitów. Żywienie pozajelitowe (całkowite lub suplementarne) jest wówczas prowadzone w domu jako domowe żywienie pozajelitowe (HPN — home parenteral nutrition).

\subsection{Leczenie żywieniowe ambulatoryjne}

Leczeniu żywieniowemu w trybie ambulatoryjnym poddawani są chorzy, dla których jest ono elementem przygotowania do leczenia onkologicznego lub opieki po nim i możliwe jest jego bezpieczne prowadzenie poza szpitalem, pod ścisłym nadzorem specjalistycznych poradni żywieniowych lub dietetycznych. Może ono być prowadzone na kilka sposobów, w zależności od indywidualnych potrzeb chorego:

- poradnictwo dietetyczne,

- suplementacja żywieniowa - doustne diety przemysłowe (ONS),

- domowe żywienie dojelitowe (HEN - home enteral nutrition) - polegające na dostarczaniu mieszanin odżywczych przez sztuczne dostępy bezpośrednio do przewodu pokarmowego chorym, którzy nie są w stanie pokryć zapotrzebowania na składniki odżywcze i energię drogą doustną. Jest ono prowadzone pod nadzorem poradni żywieniowych. Powinno być stosowane u wszystkich chorych wymagających długotrwałego leczenia żywieniowego ze sprawnym przewodem pokarmowym. Domowe żywienie pozajelitowe jest wskazane u wszystkich chorych, u których ze względu na niewydolność jelit nie jest możliwe skuteczne żywienie drogą przewodu pokarmowego. Żywienie to jest prowadzone pod ścisłą opieką poradni żywieniowych, przy użyciu standardowych diet przemysłowych lub mieszanin sporządzonych dla poszczególnego chorego. W Polsce domowe żywienia do- i pozajelitowe prowadzą wyspecjalizowane ośrodki w ramach kontraktu z Narodowym Funduszem Zdrowia.

Dr n. med. Michał Jankowski

e-mail:michaljankowski@post.pl

Otrzymano i przyjęto do druku: 10 czerwca 2015 r.

\section{Piśmiennictwo}

1. Boateng AA, Sriram K, Meguid MM i wsp. Refeeding syndrome: treatment considerations based on collective analysis of literature case reports. Nutrition 2010; 26: 156-67.

2. Byrnes MC, Stangenes J. Refeeding in the ICU: an adult and pediatric problem. Curr Opin Clin Nutr Metab Care 2011; 14: 186-92.

3. Tresley J, Sheean PM. Refeeding syndrome: recognition is the key to prevention and management. J Am Diet Assoc 2008; 108: 2105-8.

4. Marinella MA. Refeeding syndrome and hypophosphatemia. JIntensive Care Med 2005; 20: 155-9.

5. Walmsley RS. Refeeding syndrome: Screening, incidence, and treatment during parenteral nutrition. J Gastrenterol Hepatol 2013; 28 (Suppl.4): 113-7.

6. National Institute for Clinical Excellence. Nutrition support for adults. Clinical guideline CG32. 2006 Feb 1; Cited December 2012. Dostępność z URL: http//www.nice.org.uk/nicemedia/live/10978/29981/ /29981.pdf.

7. Zeki S, Culkin A, Gabe SM i wsp. Refeeding hypophosphataemia is more common in enteral than parenteral feeding in adult patients. Clin Nutr 2011; 30: 365-8.

8. Kirkland LL, Kashiwagi DT, Brantley Si wsp. Nutrition in the hospitalized patient. J Hospit Med 2013; 8: 52-8.

9. Bozzetti F. Basics in clinical nutrition: nutritional support in cancer. e-SPEN Journal 2010; 5: e148-e152.

10. Jacquelin-Ravel N, Pichard C. Clinical nutrition, body composition and oncology: a critical literature review of the synergies. Crit Rev Oncol Hematol 2012; 84: 37-46.

11. van Bokhorst-de van der Schueren MA, Guaitoli PR, Jasma EP i wsp. Nutrition screening tools: does one size fit all? A systematic review of screening tools for the hospital setting. Clin Nutr 2014; 33: 39-58.

12. Elia M, Stratton RJ. An analytic appraisal of nutrition screening tools supported by original data with particular reference to age. Nutrition 2012; 28: 477-94.

13. van Vugt JL, Resinger KW, Derikx JP i wsp. Improving the outcomes in oncological colorectal surgery. World J Gastroenterol 2014; 20: 12445-7. 
14. Braga $M$, Ljungqvist $O$, Soeters $P$ i wsp. ESPEN Guidelines on parenteral nutrition: surgery. Clin Nutr 2009; 28: 378-86.

15. Burden S, Todd C, Hill J. i wsp. Pre-operative nutrition support in patients undergoing gastrointestinal surgery. Cohrane Database Syst Rev 2012 Nov 14; 11 CD008879.

16. Senesse $\mathrm{P}$, Assenat $\mathrm{E}$, Schneider S i wsp. Nutritional support during oncologic treatment of patients with gastrointestinal cancer: Who could benefit? Cancer Treat Rev 2008; 34: 568-75.

17. Marin Caro MM, Laviano A, Pichard C i wsp. Nutritional intervention and quality of life in adult oncology patients. Clin Nutr 2007; 26: 289-301.

18. Brantley SL, Russel MK, Mogensen KM i wsp. American Society for Parenteral and Enteral Nutrition and Academy of Nutrition and Dietetics: revised 2014 standards and practice and standards of professional performance for registered dietitian nutritionists (competent, proficient, and expert) in nutrition support. J Acad Nutr Diet 2014; 114: 2001-8.e37.

19. Kłęk S. Żywienie immunomodulujace w praktyce chirurgicznej. Med Prakt 2012, wyd. specj. 1: 9-15

20. Sorensen LS, Thorlacius-Ussing O, Ramussen HH i wsp. Effects of perioperative supplementation with omega-3 fatty acids on leukotriene B4and leukotriene B5production by stimulated neutrophils in patients with colorectal cancer: a randomized, placebo-controlled intervention trial. Nutrients 2014; 6: 4043-57.

21. Zhang Y, Gu Y, Guo T i wsp. Perioperative immunonutrition for gas trointestinal cancer: A systematic review of randomized controlled trials. Surg Oncol 2012; 21: e87-e95.

22. Greco M, Carpetti G, Bretta L i wsp. Enhanced recovery program in colorectal surgery: a meta analysis of randomized controlled trials. World J Surg 2014; 38: 1531-41.

23. Spanjersberg WR, Reurings J, Keus F i wsp. Fast track surgery versus conventional recovery strategies for colorectal surgery. Cochrane Database Sys Rev 2011, Feb. 16; (2): CD007635.

24. Gustafsson UO, Scott MJ, Schwenk W i wsp. Guidelines for perioperative care in elective colonic surgery: Enhanced Recovery After Surgery (ERAS) Society recommendations. Clin Nutr 2012; 31: 783-800.

25. Jones $\mathrm{C}$, Badager SA, Hannon R. The role of carbohydrate drinks in pre-operative nutrition for elective colorectal surgery. Ann R Coll Surg Eng/ 2011; 93: 504-7.

26. Kondrup J, Allison SP, Elia M i wsp. ESPEN guidelines for nutrition screening 2002. Clin Nutr 2003; 22: 415-421.

27. Szczygieł B. Niedożywienie zwiazane z choroba. Wystepowanie, rozpoznanie. Warszawa: PZWL, 2011

28. Latifi R, Dudrick SJ. The biology and practice of current nutritional support. 2nd ed. Georgetown: Landes Bioscience, 2003.

29. Szefel J, Kruszewski WJ, Ciesielski M. Żywienie immunomodulujące w onkologii. Współ Onkol 2009; 1: 9-15.

30. Gianotti L., Braga M., Nespoli L i wsp. A Randomized controlled trial of preoperative oral supplementation with a specialized diet in patients with gastrointestinal cancer. Gastroenterology 2002; 122: 1763-1770.

31. Horie H., Okada M, Kojima M i wsp. Favourable effects of preoperative enteral Horie immunonutrition on a surgical site infection in patients with colorectal cancer without malnutrition. Surg Today 2006; 36: 1063-1068.

32. Giger-Pabst U, Lange J, Maurer C i wsp. Short-term preoperative supplementation of an immunoenriched diet does not improve clinical outcome in well-nourished patients undergoing abdominal cancer surgery. Nutrition 2013; 29: 724-729.

33. Turnock A., Calder PC, West AL i wsp. Perioperative immunonutrition in well-nourished patients undergoing surgery for head and neck cancer: evaluation of inflammatory and immunologic outcomes. Nutrients 2013; 5: 1186-1199.

34. Kabata P, Jastrzębski T, Kąkol M i wsp. Preoperative nutritional support in cancer patients with no clinical signs of malnutrition - prospective randomized controlled trial. Support Care Cancer 2015; 23: 365-370.

35. Weimann A, Braga M, Harsanyi L i wsp. ESPEN Guidelines on Enteral Nutrition: surgery including organ transplantation. Clin Nutr 2006; 25 : 224-244.

36. Rahnemai-Azar AA, Rahnemaiazar AA, Naghshizadian Ri wsp. Percutaneous endoscopic gastrostomy: indications, technique, complications and management. World J Gastroentero/ 2014; 20: 7739-7751.

37. Nutrition support in adults: Oral nutrition support, enteral tube feeding and parenteral nutrition. National Collaborating Centre for Acute Care, 2006.

38. Kapała A. Praktyczny przewodnik po ONS - oral nutrition suport. Kraków: Krakowskie Wydawnictwo Scientifica, 2015.

39. Lochs $\mathrm{H}$, Allison SP, Meier R i wsp. Introductory to the ESPEN Guidelines on Enteral Nutrition: Terminology, definitions and general topics. Clinical Nutrition 2006; 25: 180-186.
40. Podstawy żywienia klinicznego. Ed. IV. Praca zbiorowa pod redakcją L. Sobotki. Kraków: Krakowskie Wydawnictwo Scientifica, 2015.

41. Commission Directive 1999/21/EC of 25. March 1999 on dietary foods for special medical purposes.http://www.idace.org/ legislation/fsmps/ /Dir\%2099-21\%20FSMPs.pdf (accessed April 25th 2006).

42. National Institute for Health and Clinical Excellence (NICE). Nutrition support in adults: oral nutrition support, enteral tube feeding and parenteral nutrition (clinical guidelines 32). London, National Institute for Health and Clinical Excellence (NICE). 2006. http://www.npc.nhs. uk/quality/ONS/resources/borderline_substances_final.pdf.

43. Kapała A. Leczenie kacheksji nowotworowej. Praktyczny przewodnik onkologa. Warszawa: PZWL, 2013.

44. Chang SJ, Huang HH. Diarrhea in enterally fed patients: blame the diet? Curr Opin Clin Nutr Metab Care 2013 ; 16: 588-94.

45. Halmos EP. Role of FODMAP content in enteral nutrition-associated diarrhea. J Gastroenterol Hepatol 2013; 28 Suppl 4: 25-8.

46. Baldwin C, Spiro A, Ahern R i wsp. Oral nutritional interventions in malnourished patients with cancer: a systematic review and meta-analysis. J Natl Cancer Inst 2012 7; 104: 371-85.

47. Lidder PG, Lewis S, Duxbury Mi wsp. Systematic review of postdischarge oral nutritional supplementation in patients undergoing $\mathrm{Gl}$ surgery. Nutr Clin Pract 2009; 24: 388-94.

48. Ravasco P, Monteiro-Grillo I, Marques Vidal P i wsp. Impact of nutrition on outcome: a prospective randomized controlled trial in patients with head and neck cancer undergoing radiotherapy. Head Neck 2005; 27: 659-68.

49. Bjelakovic G, Nikolova D, Gluud LL i wsp. Antioxidant supplements for prevention of mortality in healthy participants and patients with various diseases. Cochrane Database Syst Rev 2008 Apr. 16; (2): CD007176.

50. Marik PE, Flemmer M. Do dietary supplements have beneficial health effects in industrialized nations: what is the evidence? JPEN J Parenter Enteral Nutr 2012; 36: 159-68.

51. Dudrick SJ. A 45-year obsession and passionate pursuit of optimal nutrition support: puppies, pediatrics, surgery, geriatrics, home TPN, ASPEN, et cetera. JPEN J Parenter Enteral Nutr 2005; 29: 272-87.

52. Bakker H, Bozzetti F, Staun M i wsp. Home parenteral nutrition in adults: a European multicentre survey in 1997. ESPEN-Home Artificial Nutrition Working Group. Clin Nutr 1999; 18: 135-40.

53. Staun M, Pironi L, Bozzetti F i wsp. ESPEN Guidelines on Parentera Nutrition: home parenteral nutrition (HPN) in adult patients. Clin Nutr 2009; 28: 467-479.

54. Bozzetti F, Arends J, Lundholm Ki wsp. ESPEN Guidelines on Parentera Nutrition: non-surgical oncology. Clin Nutr 2009; 28: 445-454.

55. Bernat JL. Ethical and legal issues in palliative care. Neurol Clin 2001 19: 969-87.

56. Morita T, Shima Y, Adachi I. Japan Palliative Oncology Study Group. Attitudes of Japanese physicians toward terminal dehydration: a nationwide survey. J Clin Oncol 2002; 20: 4699-704.

57. Chiu TY, Hu WY, Chuang RB i wsp. Nutrition and hydration for terminal cancer patients in Taiwan. Support Care Cancer 2002; 10: 630-36.

58. Jarosz J, Kapała A, Kłęk S i wsp. Konferencja uzgodnieniowa: Problemy żywieniowe w polskiej onkologii. Postępy Żywienia Klinicznego 2012; 1:29-38.

59. Arends J, Bodoky G, Bozzetti F i wsp. ESPEN Guidelines on Enteral Nutrition: Non-surgical oncology. Clin Nutr 2006; 25: 245-59.

60. Braga $M$, Ljungqvist $O$, Soeters P i wsp. ESPEN Guidelines on Parenteral Nutrition: surgery. Clin. Nutr 2009; 28: 378-386.

61. Kłęk S, Jarosz J, Jassem Ji wsp. Polskie Rekomendacje Żywienia Dojelitowego i Pozajelitowego w Onkologii — częśćll:żywienie drogą przewodu pokarmowego (żywienie dojelitowe). Onkol Prakt Klin 2013; 9: 209-215.

62. Sobotka L. Podstawy żywienia klinicznego; red. pol. wyd. T. Korta, M. Łyszkanowska. Warszawa: PZWL, 2007.

63. Correia MI, Waitzberg DL. The impact of malnutrition on morbidity, mortality, length of hospital stay and costs evaluated through a multivariate model analysis. Clin Nutr 2003; 22: 253-259.

64. Pertkiewicz M, Kłęk S. Zespół krótkiego jelita. W: Interna Szczeklika: mały podręcznik 2014/2015. Kraków: Medycyna Praktyczna, 2014;939-941.

65. Kłęk Si wsp. Standardy żywienia dojelitowego i pozajelitowego. Kraków: Krakowskie Wydawnictwo Scientifica, 2014.

66. Rekomendacje Polskiego Towarzystwa Chirurgii Onkologicznej Przetoki układu pokarmowego u chorych leczonych z powodu nowotworów: diagnostyka i leczenie. NOWOTWORY JOncol 2008; 58:447-460. 
Załącznik 1. Nutritional Risk Screening 2002

\begin{tabular}{|c|c|c|c|}
\hline \multicolumn{4}{|c|}{ Nutritional Risk Screening 2002} \\
\hline \multicolumn{2}{|c|}{ Pogorszenie stanu odżywienia } & \multicolumn{2}{|c|}{$\begin{array}{l}\text { Nasilenie ciężkości choroby (= zwiększone } \\
\text { zapotrzebowanie na składniki odżywcze) }\end{array}$} \\
\hline $\begin{array}{l}0 \text { pkt } \\
\text { brak }\end{array}$ & stan odżywienia prawidłowy & $\begin{array}{l}0 \text { pkt } \\
\text { brak }\end{array}$ & $\begin{array}{l}\text { normalne zapotrzebowanie na } \\
\text { składniki odżywcze }\end{array}$ \\
\hline $\begin{array}{l}1 \text { pkt } \\
\text { lekkie niedożywienie }\end{array}$ & $\begin{array}{l}\text { utrata m.c. > 5\% w ciągu } 3 \text { mies. } \\
\text { lub przyjmowanie pożywienia } \\
<50-75 \% \text { zapotrzebowania } \\
\text { w ciągu ostatniego tygodnia }\end{array}$ & $\begin{array}{l}1 \text { pkt } \\
\text { lekkie niedożywienie }\end{array}$ & $\begin{array}{l}\text { złamanie kości biodrowej } \\
\text { choroby przewlekłe z ostrymi } \\
\text { powikłaniami: marskość wątroby, } \\
\text { POChP, przewlekła hemodializa, } \\
\text { cukrzyca, choroby nowotworowe }\end{array}$ \\
\hline $\begin{array}{l}2 \text { pkt } \\
\text { średnie niedożywienie }\end{array}$ & $\begin{array}{l}\text { utrata m.c. > 5\% w ciągu } 2 \text { mies. } \\
\text { lub BMI 18,5-20,5 z towarzyszącym } \\
\text { pogorszeniem stanu ogólnego } \\
\text { lub przyjmowanie pożywienia } \\
\text { w granicach } 25-60 \% \text { normalnego } \\
\text { zapotrzebowania w ciągu } \\
\text { ostatniego tyg. }\end{array}$ & $\begin{array}{l}2 \text { pkt } \\
\text { średnie niedożywienie }\end{array}$ & $\begin{array}{l}\text { duże operacje brzuszne, udar } \\
\text { mózgu, ciężkie zapalenie płuc, } \\
\text { złośliwe choroby hematologiczne }\end{array}$ \\
\hline $\begin{array}{l}3 \text { pkt } \\
\text { ciężkie niedożywienie }\end{array}$ & $\begin{array}{l}\text { utrata m.c. }>5 \% \text { w ciągu } \\
1 \text { mies. (> 15\% w ciągu } 3 \text { mies.) } \\
\text { lub BMI < 18,5 z towarzyszącym } \\
\text { pogorszeniem stanu ogólnego } \\
\text { lub przyjmowanie pożywienia } \\
\text { w granicach 0-25\% normalnego } \\
\text { zapotrzebowania w ciągu } \\
\text { ostatniego tyg. }\end{array}$ & $\begin{array}{l}3 \text { pkt } \\
\text { ciężkie niedożywienie }\end{array}$ & $\begin{array}{l}\text { uraz głowy, przeszczep szpiku, } \\
\text { kostnego, pacjenci wymagający } \\
\text { intensywnej terapii (stan oceny } \\
\text { w skali APACHE > } 10 \text { pkt) }\end{array}$ \\
\hline \multicolumn{2}{|c|}{ Razem: ........ pkt } & \multicolumn{2}{|c|}{ Razem: ....... pkt } \\
\hline \multicolumn{2}{|c|}{ wiek } & \multicolumn{2}{|c|}{ jeżeli chory ma > 70 lat, dodaj 1 punkt do sumy punktów } \\
\hline \multicolumn{4}{|c|}{ SUMA PUNKTÓW: ....................... } \\
\hline \multicolumn{4}{|c|}{$\begin{array}{r}\text { suma pkt }>\text { lub }=3 \text { oznacza ryzyko niedożywienia i konieczność rozpoczęcia wspomagania (leczenia) żywieniowego } \\
\text { suma pkt }<3 \text { oznacza, że należy powtórzyć badanie przesiewowe po tygodniu }\end{array}$} \\
\hline
\end{tabular}


Załącznik 2. Subiektywna globalna ocena stanu odżywienia (SGA)

Subiektywna globalna ocena stanu odżywienia (SGA)

I. Wywiad

1. Wiek (lata) ....... wzrost $(\mathrm{cm})$....... masa ciała $(\mathrm{kg})$........ płeć $\quad \square \mathrm{K} \quad \square \mathrm{M}$

2. Zmiana masy ciała utrata masy w ostatnich 6 miesiącach ......... (kg) ........(\%)

zmiana masy ciała w ostatnich 2 tygodniach:

$\square$ zwiększenie $\square$ bezzmian $\square$ zmniejszenie

3. Zmiany w przyjmowaniu pokarmów

$\square$ bez zmian $\quad \square$ zmiany: czas trwania ........... (tygodnie)

Rodzaj diety:

$\square$ zbliżona do optymalnej dieta oparta na pokarmach stałych

$\square$ dieta płynna kompletna

$\square$ dieta płynna hipokaloryczna $\quad \square$ głodzenie

4. Objawy ze strony przewodu pokarmowego (utrzymujące się ponad 2 tygodnie)
$\square$ bez objawów
$\square$ nudności
$\square$ wymioty
$\square$ biegunka
$\square$ jadłowstręt

\section{Wydolność fizyczna}

$\square$ bez zmian

$\square$ zmiany: czas trwania ........ (tygodnie)

rodzaj: $\quad \square$ praca w ograniczonym zakresie

$\square$ chodzi

$\square$ leży

6. Choroba a zapotrzebowanie na składniki odżywcze:

wzrost zapotrzebowania metabolicznego wynikający z choroby
$\square$ brak
$\square$ mały
$\square$ średni
$\square$ duży

II. Badania fizykalne

należy określić stopień zaawansowania:

( 0 - bez zmian, 1 - lekki, 2 - średni, 3 - ciężki)

$\square$ utrata podskórnej tkanki tłuszczowej nad mięśniem trójgłowym i na klatce piersiowej (stopień .....)

$\square$ zanik mięśni (czworogłowy, naramienny) (stopień ......)

$\square$ obrzęk nad kością krzyżową (stopień .....)

$\square$ obrzęk kostek (stopień .....)

$\square$ wodobrzusze (stopień ......)

III. Subiektywna globalna ocena stanu odżywienia (SGA):

$\square$ prawidłowy stan odżywienia (stopień A)

$\square$ podejrzenie niedożywienia lub niedożywienie średniego stopnia (stopień B)

$\square$ wyniszczenie (stopień C)

(podpis osoby przeprowadzającej ocenę) 